•生物编目・

\title{
布尼亚病毒目新分类概述
}

唐 霜 沈 姝 史君明方耀辉 王华林 胡志红邓菲*

(中国科学院武汉病毒研究所微生物菌毒种保藏中心, 武汉 430071)

摘要: 布尼亚病毒目中许多病毒是新发现的, 而且对人类健康构成威胁或潜在威胁。本文结合国际病毒分类委员 会 (ICTV) 2017年第十次报告, 针对新列的布尼亚病毒目的最新分类系统, 总结了该类病毒 ICTV 分类的历史变 化情况，对其下属各病毒科的分类、中英文定名、代表种、病毒形态、病毒基因组结构、编码蛋白、病毒主要传 播媒介、病毒感染宿主、地理分布、理化特性等进行了介绍, 并且基于病毒基因组的编码RdRp的基因序列对 9 个 科13个属的布尼亚病毒做了系统发育分析。

关键词: 布尼亚病毒目; 分类; ICTV; 变化; 病毒

\section{A review and novel classification of Bunyavirales}

\author{
Shuang Tang, Shu Shen, Junming Shi, Yaohui Fang, Hualin Wang, Zhihong Hu, Fei Deng* \\ Microorganisms \& Viruses Culture Collection Center, Wuhan Institute of Virology, Chinese Academy of Sciences, Wuhan \\ 430071
}

\begin{abstract}
Most members of the Bunyavirales could infect humans and animals and thus pose great potential threat to public health. According to the $10^{\text {th }}$ Report on Virus Taxonomy released by the International Committee on Taxonomy of Viruses (ICTV, 2017), the taxonomy of Bunyaviruses has been updated. Based on the information of this report, we highlight the taxonomy of the new Bunyavirales and summarize the historical changes of ICTV classification of this virus, including classification, designation, typical species, genomic structures, encoding protein, major vectors and hosts, geographic distribution, and specific viral properties. In addition, based on the viral genome-encoded RdRp gene sequence, a phylogenetic analysis is performed for the all nine families and 13 genera as well as the representative species of Bunyavirales.
\end{abstract}

Key words: Bunyavirales; taxonomy; ICTV; change; virus

布尼亚病毒名称源自1943年在非洲乌干达西 部布尼亚韦拉地区分离到的新病毒一一布尼亚韦拉 病毒(Bunyamwera virus)。随着世界范围内布尼亚病 毒引起的新发或再发传染病暴发流行, 布尼亚病毒 已受到人们越来越多的关注(Guterres, 2017)。国际 病毒分类委员会(International Committee on Taxonomy of Viruses, ICTV)于2017年3月在线发布了最 新的病毒分类第十次报告, 在前几次病毒分类报告 的基础上, 将病毒分为 9 个目、131个科、46个亚科、 803 个属和 4,853 个种(Lefkowitz et al, 2017)。报告中, ICTV布尼亚病毒研究小组提出并对此前的布尼亚
病毒科(Bunyaviridae)进行了紧急修订。原布尼亚病 毒科被ICTV正式命名于1975年, 且在2016年ICTV 病毒分类报告之前, 该科下设 5 个属, 即布尼亚病 毒属(Orthobunyavirus)、白蛉病毒属(Phlebovirus)、 内罗病毒属(Nairovirus)、汉坦病毒属(Hantanvirus) 和番茄斑萎病毒属(Tospovirus)。但在此前已报道的 约530种布尼亚病毒中, 约有半数以上无法被分类 定位到这5个属中。另外, 近年来发现了许多新的病 毒遗传序列, 遗传进化分析显示这些新病毒可以被 分类定位到布尼亚病毒中, 包括一些只发现了两个 节段的负链RNA病毒, 以及多节段负链RNA的植 
物病毒, 如以前归类到自由浮动的病毒属 (free-floating genera)中的伊马拉病毒属(Emaravirus) 以及纤细病毒属(Tenuivirus) (Elbeaino et al, 2009a; Plyusnin, 2011; Tokarz et al, 2014; Li et al, 2015)等。 为了更好地反映各种病毒的进化关系, 这些病毒在 此次最新的病毒分类报告中都被统一归入布尼亚 病毒目，即将原布尼亚病毒科升级为布尼亚病毒目 (Bunyavirales)。

根据基因组中主要编码蛋白RNA序列的遗传 进化关系，新命名的布尼亚病毒目可分为 9 科 13 属, 科分别为费拉病毒科(Feraviridae)、无花果花叶病毒 科(Fimoviridae)、汉坦病毒科(Hantaviridae)、米卡多 病毒科(Jonviridae)、内罗病毒科(Nairoviridae)、泛 布尼亚病毒科 (Peribunyaviridae)、幻影病毒科 (Phasmaviridae)、白纤病毒科(Phenuiviridae)和番茄 斑萎病毒科(Tospoviridae); 除 1 个为重命名的科 (Peribunyaviridae)外, 其余8个均为新命名的科。依 据ICTV历次报告, 我们将布尼亚病毒的目、科、属 的分类变更历史，如新增、重命名、变动等信息进 行了总结(表1)。

新的布尼亚病毒目是由球形、有包膜和多节段 的负链RNA病毒组成。经典的布尼亚病毒多为三节 段负链RNA病毒, 新的布尼亚病毒则有二到八个节 段的负链RNA。除少数病毒只发现了 L 和S两个RNA 片段序列外, 大多数布尼亚病毒基因组均包含大 $(\mathrm{L}) 、$ 中 $(\mathrm{M})$ 和小 $(\mathrm{S})$ 三个 RNA节段, 分别编码病毒 RNA依赖的RNA聚合酶(RNA-dependent RNA polymerase, RdRp)、囊膜糖蛋白(Glycoprotein, GP)以 及核衣壳蛋白(Nucleoprotein, NP)。已分离得到的布 尼亚病毒粒子大多呈球形颗粒状, 直径约80-120 nm, 但也有少数如汉坦病毒直径大到 $210 \mathrm{~nm}$, 还有一种 米卡多病毒可呈约 $60 \mathrm{~nm}$ 、长度达600 nm的杆状颗 粒, 另外纤细病毒属的植物病毒则呈约 3-8 $\mathrm{nm}$ 的 丝状颗粒。病毒粒子均具有脂质双层包膜, 包膜外 伸出许多糖蛋白刺突, 不同病毒刺突大小和形状有 差异。

经典的布尼亚病毒自然感染脊椎动物、节肢动 物(蚊、蜱、白蛉等)和植物, 一般由媒介传播, 有蚊 媒、蜱媒和白蛉媒等节肢动物传播类型, 植物间的 病毒传播也可以通过昆虫媒介来完成。有些布尼亚 病毒在其节肢动物媒介中, 可经卵、交配或胚胎期 传播, 但通常不会引起媒介昆虫的病变; 密切接
触有病毒血症的动物或患者也是另一种重要的感 染烈性布尼亚病毒的方式。布尼亚病毒能在一些哺 乳类动物细胞、蚊细胞以及鸡胚中培养生长。烈性 布尼亚病毒对人感染可引起高热、出血(如克里米 亚-刚果出血热)、脑炎(如加利福尼亚脑炎病毒)及 血小板减少(如发热伴血小板减少综合征)等临床 症状。新的布尼亚目在原来可感染植物的一个病毒 属(原番茄斑萎病病毒属)基础上，新增可感染植物 的伊马拉病毒属和纤细病毒属, 可侵染多种经济 作物，如大豆、花生、番茄、西瓜、辣椒、洋葱和 烟草等。植株被侵染症状的变化主要受病毒种类、 环境及寄主植物生育状况等因素影响，常见症状 为叶片产生黄化斑点、斑驳、皴皱、萎调甚至严重 坏疽等。

布尼亚病毒能耐受低温而对高温敏感，煮沸可 迅速灭活, 对酸、脂溶剂和去垢剂如乙醚、氯仿、 去氧胆酸钠等敏感。低浓度甲醛可使其灭活而保持 其抗原性(Korneyeva, 2002; 方元等, 2015)。预防控 制布尼亚病毒感染须尽量减少与虫媒昆虫或野生 动物的接触, 做好个人防护, 防止虫媒叮咬等。

新的布尼亚病毒目作为病毒分类系统病毒目 中的新成员, 其所属各病毒科的系统分类较之前的 报告变化很大, 为及时了解布尼亚病毒目的国际病 毒分类系统，本文将ICTV 2017分类报告公布的新 的布尼亚病毒目中各科分类、定名、基因组结构、主 要传播媒介和感染宿主等信息进行了整理(附录1), 并基于 $\mathrm{RdRp}$ 的序列对布尼亚病毒开展了系统发育 分析。以下分别对其下 9 个科的病毒进行简单介绍。

\section{费拉病毒科}

布尼亚病毒目中新定义的病毒科，包含 1 个病 毒属：正费拉病毒属(Orthoferavirus)，仅有1个病毒 种：费拉克正费拉病毒 (Ferak orthoferavirus, FERV)。该病毒分离自科特迪瓦塔伊国家公园采集 的库蚊和冈比亚按蚊(Marklewitz et al, 2011), 病毒 粒子有囊膜包裹，呈多形性球形，直径60-120 nm, 与白纤病毒科的格克病毒属(Goukovirus)和泛布尼 亚病毒科的赫伯病毒属(Herbevirus)病毒粒子形态 相似。

费拉病毒基因组由 $\mathrm{L} 、 \mathrm{M}$ 和 $\mathrm{S}$ 三个RNA节段组成, 长度分别为 $6.9 \mathrm{~kb} 、 4.3 \mathrm{~kb}$ 和 $1.5 \mathrm{~kb}$ 。L片段编码RdRp; $\mathrm{M}$ 片段编码糖蛋白前体GP并可被剪切为非结构蛋 
表1 布尼亚病毒分类变化历史简表

Table 1 Time points for changes in bunyavirus taxonomy

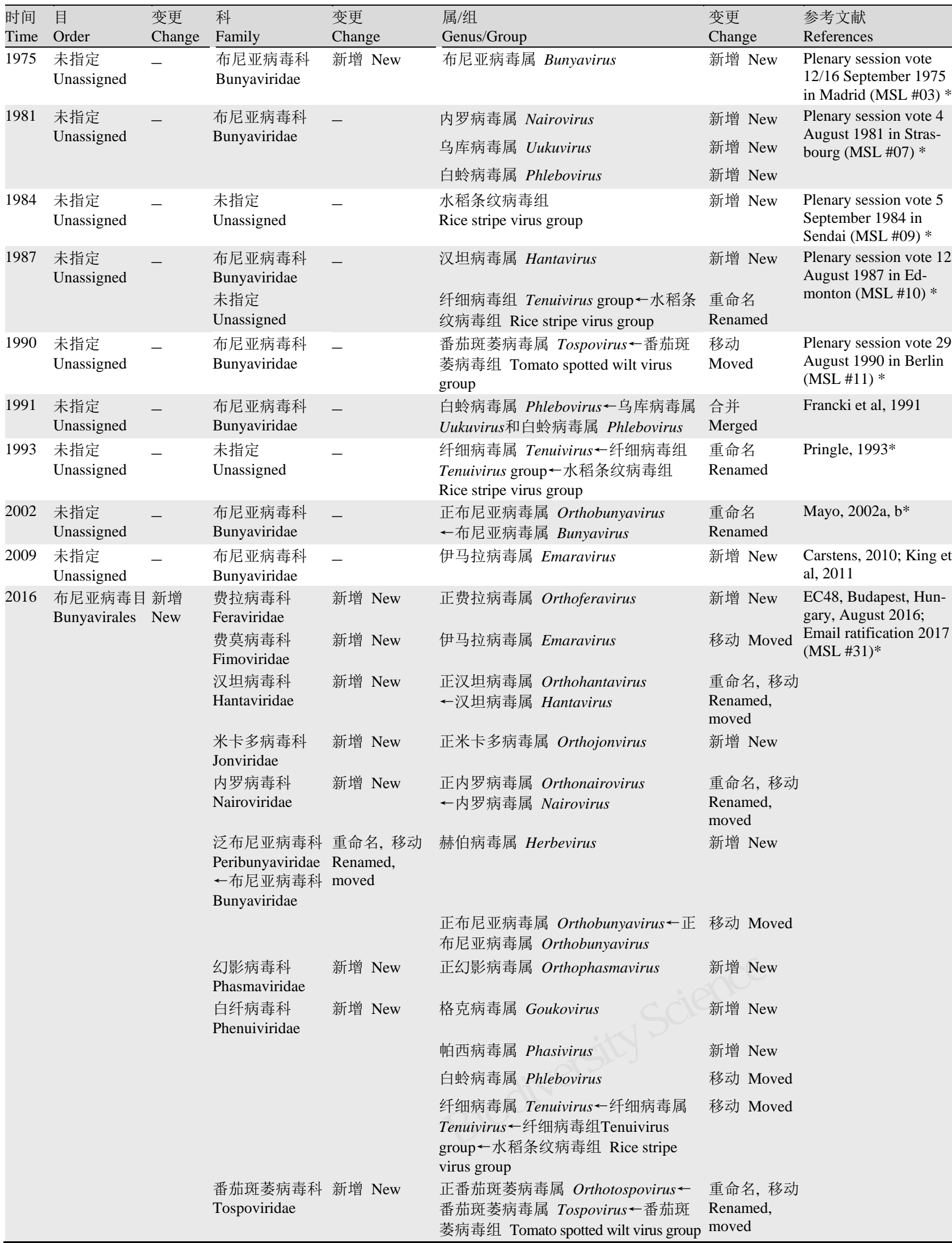

* 全部会议记录见网络 * Minutes of these Plenary Sessions are available at: https://talk.ictvonline.org/files/ictv_documents/m/plenary_minutes/default.aspx 


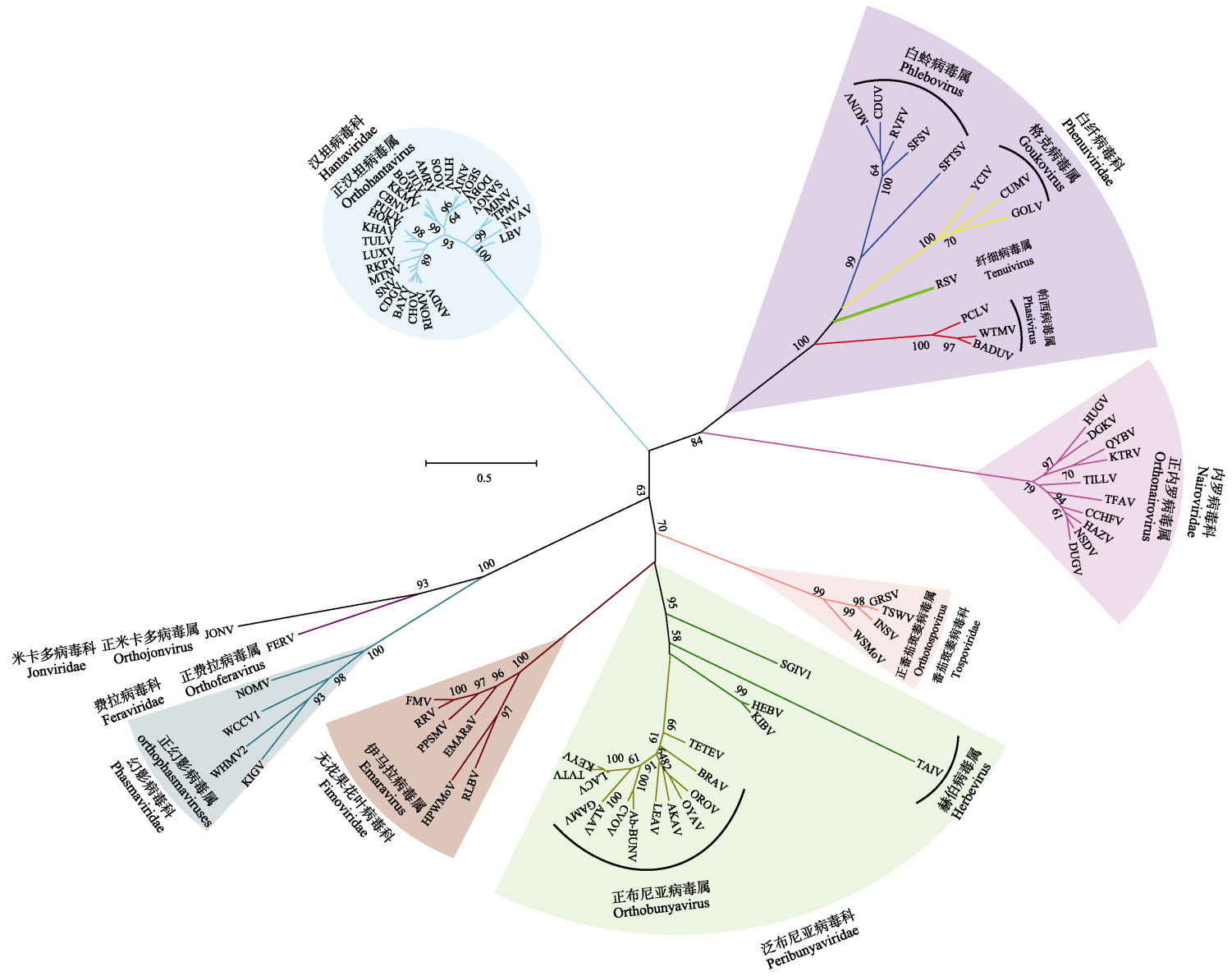

图1 布尼亚病毒目的最大相似度进化树。基于布尼亚病毒目各科(属)病毒RNA依赖的RNA聚合酶(RdRp)氨基酸序列构建的 进化树, 利用Bootstrap方法对各节点进行1,000次验证, 仅显示各科(属)的主要分支节点的数值。病毒名称的缩写请参见附录2。 Fig. 1 The Maximum like-hood phylogenetic tree of Bunyavirales. The tree is built based on the RdRp protein sequences from the virus members of Bunyavirales, and tested by the Bootstrap Method with 1,000 replicates. The bootstrap value at the main modes of each family and genus are listed. Abbreviation of viruses name, please see the Appendix 2.

白(NSm)和包膜糖蛋白(Gn和Gc); S片段编码NP和 非结构蛋白NSs。NSs是S片段RNA正链编码的非结 构蛋白。NSs最初被认为是一个致病因子，能增强症 状表现。近年来的研究显示NSs除抑制RNA沉默外, 很可能在病毒复制、转录过程中起重要作用。成熟 的病毒颗粒包装了3种主要的病毒结构蛋白: Gn、 Gc和NP (Marklewitz et al, 2011)。

费拉病毒主要感染蚊子(Culex, Anopheles, Uranotaenia), 且仅能在蚊子细胞中复制扩增, 不能感 染脊椎动物细胞, 属于昆虫宿主限制性病毒 (insect-restricted virus) (Marklewitz et al, 2015)。此外, 有学者通过高通量测序方法在水黾和昆虫样本中 检测到三峡水黾病毒2 (Sanxia water strider virus 2) 和武汉昆虫病毒2 (Wuhan insect virus 2), 基于RdRp 序列的进化分析结果显示, 这两株病毒与 Ferak virus 具有较近的亲缘关系，同属Feravirus分支 (Junglen, 2016)。但目前尚未获得两株病毒的全基因 组序列, 故未收录在ICTV 2017分类报告中。

\section{2 无花果花叶病毒科}

布尼亚病毒目中新定义的病毒科，也称费莫病 毒科, 包含 1 个病毒属: 伊马拉病毒属(Emaravirus), 该属因取其代表种欧洲花楸环斑病相关病毒 (European mountain ash ringspot-associated virus, EMARaV)的英文名称中每个单词的首字母而得名 (Mielke \& Muehlbach, 2007)。无花果花叶病毒科的 拉丁文名称Fimoviridae则是取自另一代表种无花果 花叶病毒Fig mosaic emaravirus中的“Fi-”和“mo-”而 得名。

无花果花叶病毒科的病毒颗粒有囊膜包裹, 呈 
球形, 直径为 80-200 $\mathrm{nm}$, 具有多节段的负链 RNA。伊马拉病毒属含有 9 个病毒种, 各病毒种基因 组有所差异, 分别包含 4-8个RNA节段, 长度为 1.1-7.1 kb不等, 如代表种欧洲花楸环斑病病毒为4 节段病毒, 新近有学者分离得到6节段(Elbeaino et al, 2015)的无花果花叶病毒(Fig mosaic emaravirus, FMV), 而非之前报道的4节段(Elbeaino et al, 2009a, b; Ishikawa, 2012), 高地平原小麦病毒(High plains wheat mosaic emaravirus, HPWMoV)为8节段病毒 (Skare et al, 2006; Tatineni et al, 2014)。无花果花叶 病毒基因组中前3个节段RNA-1、RNA-2和RNA-3, 分别编码RdRp、GP和NP, 其他基因节段编码的蛋 白生物学功能尚不明确。

无花果花叶病毒科成员与其他布尼亚病毒相 比有较大差异, 但分类学仍然将其归为布尼亚病毒 目, 主要依据以下几点: (1)病毒均为分节段的负义 单链RNA病毒; (2)病毒基因组中包含的3个RNA节 段分别编码RdRp、GP和NP, 这些蛋白氨基酸序列 与布尼亚病毒相应蛋白序列具有较高相似性; (3)病 毒粒子有包膜包裹; (4)病毒基因组结构与经典布尼 亚病毒类似，所有RNA节段拥有保守的反向互补 $5^{\prime}$ 和3'末端(McGavin et al, 2012; Elbeaino et al, 2014; Tatineni et al, 2014; Zheng et al, 2017)。

无花果花叶病毒科病毒可感染植物, 导致环 斑、花斑、丛矮、枝小和不育等症状。如EMARaV 感染花楸(Sorbus)会引起植物出现环斑(Mielke \& Muehlbach, 2007), 玫瑰从矮病毒(Rose rosette emaravirus)感染玫瑰导致植株发育不良, 出现从矮症状 (Laney et al, 2011), 表明该科病毒可以通过植物嫁 接等机械方式和螨类(瘤瘞螨属Aceria, 植羽瘞螨属 Phytoptus, 叶刺瘘螨属Phyllocoptes)等节肢动物传 播。目前还没有证据表明该病毒可通过种子垂直传 播和土壤传播。该类病毒耐低温, 对高温敏感, 者 沸可迅速灭活; 对酸敏感, 对脂溶剂和去垢剂如乙 醚、氯仿、去氧胆酸钠等敏感。低浓度甲醛可使其 灭活而保持其抗原性(Korneyeva, 2002)。

\section{3 汉坦病毒科}

布尼亚病毒目中新定义的病毒科, 只有 1 个病 毒属, 即正汉坦病毒属(Orthohantavirus), 该属包含 41个病毒种, 代表种为正汉坦病毒(Hantaan orthohantavirus), 原名汉坦病毒(Hantaan hantavirus), 因
分离自韩国汉坦河附近的黑线姬鼠 (Apodemus agrarius)肺组织而得名(Lee et al, 1978)。汉坦病毒颗 粒呈圆形或卵圆形, 直径80-210 $\mathrm{nm}$, 平均直径 120 $\mathrm{nm}$, 有双层膜, 内浆为疏松的颗粒性线状结构, 表 面具有独特的方格形亚单位结构等。该科病毒基因 组RNA有 $\mathrm{L} 、 \mathrm{M}$ 和 $\mathrm{S}$ 三个节段，与布尼亚病毒目其他 科病毒的主要区别在于：其RNA分子 $3^{\prime}$ 端独特的保 守序列 AUCAUCAUCUG，5 末端的核苷酸序列 UAGUAGUAUGC，共同构成了汉坦病毒科的基因 特征(Mir \& Panganiban, 2005)。该科病毒的膜蛋白 构成病毒最外层包膜表面的刺突状结构, 存在血凝 素抗原和中和抗原决定簇, 可诱导宿主产生中和抗 体。汉坦病毒科成员间血清学亲缘关系近, 但与布 尼亚病毒目其他科成员则没有抗原亲缘关系。

通常认为, 汉坦病毒科是布尼亚病毒目中唯一 不以节肢动物为宿主的病毒科, 而是经啮齿动物和 食虫类动物进行传播，它们偶尔也感染人类，最近 有学者陆续报道从蝙蝠中发现汉坦病毒(Jonsson et al, 2010; Arai et al, 2013; Zhang, 2014; Witkowski et al, 2016)。欧美学者普遍认为汉坦病毒不存在节肢 动物宿主(Marklewitz et al, 2015), 但中国、俄罗斯、 日本等学者发现，革螨(Laelapinae)、恙螨(Trombiculidae)、细蚤(Leptopsylla) 和客蚤(Xenopsylla)等 都存在汉坦病毒的自然感染现象。实验表明, 携带 病毒的螨、蚤可以通过叮咬的方式感染鼠，且汉坦 病毒还能经卵垂直传播(Yu \& Tesh, 2014); 但寄生 螨及蚤是否是人类感染汉坦病毒的主要媒介或来 源, 仍有待进一步研究证实。汉坦病毒可引起肾综 合征出血热(Hemorrhagic fever with renal syndrome, HFRS)和肺综合征(Hantavirus pulmonary syndrome, HPS)。HFRS以发热、出血、肾功能损害和免疫功 能紊乱为主要特征。目前世界上有30多个国家都存 在HFRS, 主要分布在欧亚大陆, 发病最多的是中 国、俄罗斯、韩国、芬兰、挪威、瑞典和丹麦等国。 HPS主要分布在美国、加拿大，南美洲的阿根廷、 玻利维亚、巴西、智利、巴拉圭、乌拉圭，中美洲 的巴拿马等国家。HPS以肺浸润及肺间质水肿、呼 吸若迫和衰竭为主要特征, 我国至今尚未发现HPS (Scholz et al, 2017; Jiang et al, 2017; Khaiboullina et al, 2005; Golovljova et al, 2007)。

汉坦病毒在培养的脊椎动物细胞上不产生可 检测的细胞病理学反应, 不建立持续性感染, 在感 
染啮齿动物中不产生病症。由于宿主动物的不同, 不同地区流行着不同型别的汉坦病毒, 病毒与宿主 间存在一定的共进化关系。汉坦病毒抵抗力弱, 不 耐热不耐酸, 对脂溶剂敏感, 乙醚、氯仿、丙酮等 均可灭活，一般消毒剂及酒精也可以灭活。在 $56^{\circ} \mathrm{C}$ $30 \mathrm{~min}$ 或 $100^{\circ} \mathrm{C} 1 \mathrm{~min}$ 以及pH为3-5的环境均可灭活 (Korneyeva, 2002; Khaiboullina et al, 2005)。预防汉 坦病毒主要是加强灭鼠、防鼠、灭虫、消毒和个人 防护措施。

\section{米卡多病毒科}

布尼亚病毒目中新定义的病毒科, 仅有 1 个病 毒属: 正米卡多病毒属(Orthojonvirus), 仅包含1个 病毒种: 约赫特正米卡多病毒(Jonchet orthojonvirus, JONV)。JONV分离自非洲科特迪瓦的塔伊国家公 园采集的库蚊。病毒粒子具有囊膜包裹, 呈现两种 不同的形态: 一种是直径约 $80 \mathrm{~nm}$ 的球形病毒颗粒, 是典型的布尼亚病毒所具有的病毒形态; 另一种则 是直径约 $60 \mathrm{~nm}$ 、长度达 $600 \mathrm{~nm}$ 的杆状颗粒(Junglen, 2016), 因这种杆状病毒形态与著名的米卡多挑竹 签游戏(Mikado)极为相似, 法语翻译为Jonchet, 故 而得名。新定义的正米卡多病毒属和米卡多病毒科 则沿用了这一名称。

米卡多病毒基因组包含 $\mathrm{L} 、 \mathrm{M}$ 和 $\mathrm{S}$ 三个 RNA 节 段。L片段长度为 $6.9 \mathrm{~kb}$, 编码 $\mathrm{RdRp}$, 在 $\mathrm{N}$-端有一个 核酸内切酶结构域; $\mathrm{M}$ 片段长度为5.4 kb, 是目前所 知的布尼亚病毒中最长的M片段, 编码 GP, 成熟后 可被剪切为 $\mathrm{Gn} 、 \mathrm{Gc}$ 和NSm; $\mathrm{S}$ 蛋白长度 $1.7 \mathrm{~kb}$, 编码 $\mathrm{NP}$ 和NSs。米卡多病毒粒子已鉴定出了6 种病毒蛋 白, 根据蛋白大小分别是RdRp、GP、Gn、Gc、NP 和NSs，提示成熟的米卡多病毒颗粒包装了这6种蛋 白(Marklewitz et al, 2015; Junglen, 2016)。

米卡多病毒能在多种蚊子细胞中复制扩增, 但 不能感染脊椎动物细胞, 属于昆虫宿主限制性病毒 (Marklewitz et al, 2011, 2013, 2015)。

\section{内罗病毒科}

布尼亚病毒目中新定义的病毒科, 现确定有 1 个病毒属, 即正内罗病毒属(Orthonairovirus), 该属 下含 12 个病毒种, 代表种为正杜贝病毒(Dugbe orthonairovirus), 原名杜贝病毒(Dugbe nairovirus)。该 科病毒粒子直径80-120 nm, 呈圆形或卵圆形, 有
脂质双层膜，表面具有 5-10 nm的糖蛋白突起。病毒 基因组RNA有 $\mathrm{L} 、 \mathrm{M}$ 和 $\mathrm{S}$ 三个片段，三个节段末端核 苷酸序列相同， $3^{\prime}$ 端为 AGAGUUUCU， $5^{\prime}$ 端为 UCUCAAAGA，两端由氢键连接成环状; L片段为 11.7-12.3 kb, M片段为4.0-5.4 kb, S片段为1.5-2.3 kb, 它们分别编码RdRp、Gn、Gc和NP (Walker et al, 2015)。

内罗病毒科病毒大部分以蜱、蚊为媒介传播, 部分内罗病毒也可在蠓、風子等节肢动物中传播, 或者通过蜱虫在蝙蝠、鸟、植物、䖝子或啮齿动物 宿主之间进行传播(Kuhn et al, 2016); 病毒感染节 肢动物媒介后, 不引起媒介昆虫的病变; 有报道显 示气溶胶传播也是某些内罗病毒科病毒的一种 传播方式; 各成员间具有不同程度的血清学交叉 反应。

内罗病毒科病毒地理分布广泛，在非洲、亚洲、 澳洲、欧洲和美洲均有报道，具有传染性强、致死 率高等特点, 能够引起多种严重的人类及动物传染 性疾病。其中最具有重要公共卫生影响的是正克里 米亚-刚果出血热病毒(Crimean-Congo hemorrhagic fever orthonairovirus), 原名克里米亚-刚果出血热 病 毒 (Crimean-Congo hemorrhagic fever virus, CCHFV)。克里米亚-刚果出血热(Crimean-Congo hemorrhagic fever, CCHF)是一种由CCHFV引起的, 流行于中国新疆南部、俄罗斯北部、中东、南部欧 亚大陆及非洲撒哈拉地区的烈性传染性疾病，以发 热、出血为典型症状，其平均病死率在3-30\% (Ergonul, 2006, 2012); 在我国首次被发现于新疆地区, 又称为新疆出血热 (Xinjiang hemorrhagic fever, XHF)。正内罗绵羊病病毒(Nairobi sheep disease orthonairovirus), 原名内罗绵羊病病毒 (Nairobi sheep disease nairovirus), 可引起家畜严重疾病, 致 死率高达 $90 \%$, 主要表现为肠胃炎、肾小球肾炎以 及明显的贫血和血蛋白量减少等临床症状，在人类 主要引起发热和关节炎, 一般临床症状表现较轻 (Davies, 1997; Marczinke \& Nichol, 2002)。

遗传进化分析表明，内罗病毒科病毒分为两个 主要的单系群体, 即硬蜱 (Ixodidae) 组和软蜱 (Argasidae)组。内罗病毒科病毒能耐受低温而对高 温敏感，煮沸可迅速灭活，室温下液体环境中可存 活 $15 \mathrm{~d}$, 对紫外线敏感, $3 \mathrm{~min}$ 内失活; 在 $4^{\circ} \mathrm{C} 10 \mathrm{~d}$ 、 $20^{\circ} \mathrm{C} 2 \mathrm{~d} 、 37^{\circ} \mathrm{C} 12 \mathrm{~h} 、 60^{\circ} \mathrm{C} 10 \mathrm{~min} 、 100^{\circ} \mathrm{C} 2 \mathrm{~min}$ 
完全灭活; pH为7.0-9.0环境中感染性和抗原性最 好。对酸敏感, 对脂溶剂和去垢剂如乙醚、氯仿, 去 氧胆酸钠等敏感。低浓度甲醛可使其灭活而保持其 抗原性; $1: 1000$ 次氯酸钠可显著降低其感染度; 消 毒剂甲酚皇、石碳酸、乙醇等在常规浓度可以很快 将其灭活(朱进等, 2005)。灭蜱、防蜱是预防和控制 内罗病毒科病毒的关键环节。

\section{6 泛布尼亚病毒科}

布尼亚病毒目中唯一重命名的病毒科, 由 2 个 病毒属组成: 赫伯病毒属下含 4 个病毒种, 正布尼 亚病毒属(Orthobunyavirus)含48个病毒种。基因组 包含 $\mathrm{L} 、 \mathrm{M}$ 和 $\mathrm{S}$ 三个RNA节段。

赫伯病毒属和正布尼亚病毒属的病毒粒子形 态大致相同。细胞内未成熟的赫伯特病毒颗粒呈球 形, 直径为50-60 nm。成熟的赫伯特病毒有囊膜包 裹, 呈球形, 直径 90-110 nm (Marklewitz et al, 2013)。正布尼亚病毒颗粒呈多形性的球形, 直径为
$18 \mathrm{~nm}$ 左右长度的刺突状(Junglen, 2016)。

赫伯病毒属和正布尼亚病毒属的病毒基因编 码策略稍有不同。赫伯病毒属病毒的L片段长度约 7.3-7.5 kb, 编码RdRp; S片段长度约1.1-1.2 kb, 编 码NP; M片段长度在 4 个病毒种中有所不同: 赫伯 特病毒(Herbert herbevirus, HEBV)、塔伊病毒(Taï virus, TAIV)和吉贝利病毒(Kibale virus, KIBV) M片 段长度约2.6-2.8 kb, 编码的 $\mathrm{GP}$ 可被剪切为 $\mathrm{Gn}$ 和 $\mathrm{Gc}$; 双忝昆虫病毒1 (Shuangao insect virus 1, SHUV-1)的 $\mathrm{M}$ 片段长度为 $4.8 \mathrm{~kb}$, 编码的 GP按 $\mathrm{N}$-段至C-端顺序 可被剪切为Gn-NSm-Gc。正布尼亚病毒属病毒L片 段长 6.8-7.0 kb，M 片段长 3.4-5.1 kb，S 片段长 0.7-1.1 kb。与赫伯病毒属的双忝昆虫病毒 1 相同, 正布尼亚病毒的L片段编码RdRp, M片段编码的GP 能被剪切为Gn-NSm-Gc, S片段除编码NP之外, 在 核蛋白编码区内自不同的AUG位点起始还编码NSs (Junglen et al, 2009; Elliott, 2014)。

赫伯特病毒是在非洲科特迪瓦的塔伊国家公 园、乌干达吉贝利国家公园和加纳的库马西城采集 的库蚊中检测并分离得到的。赫伯病毒属病毒可感 染蚊(库蚊属、按蚊属、蓝带蚊属等), 并可在蚊子细 胞中复制和扩增, 是昆虫宿主限制性病毒(Marklewitz et al, 2013)。2014年韩国境内暴发的一种猪的
严重疾病与HEBV和格里克病毒 (Gouleako goukovirus, GOLV)有关(Chung, 2014), 但在科特迪瓦地 区猪体内并没有出现相似结果, 目前认为在没有更 进一步的证据证明该病毒感染了猪或其他脊椎动 物之前, 该病毒不被作为流行性病原或虫媒病毒 (Junglen et al, 2015)。

最近报道的SHUV-1是在中国浙江省温州市双 乔村采集的混合昆虫样本中检测到的, 之前尚未有 人或动物感染该病毒的报道( Li et al, 2015)。正布尼 亚病毒可感染人并引起严重的疾病如发热、脑炎、 出血热等。有的正布尼亚病毒还可感染反刍动物引 起流产和畸胎。正布尼亚病毒属中的拉克洛斯病毒 (La Crosse Virus, LACV)可导致大面积人群的无症 状感染, 给疾病的防治带来困难。大多数正布尼亚 病毒可由蚊虫叮咬传播, 少数由蜱虫、床䖝和蠓等 昆虫叮咬传播。因此，预防和控制正布尼亚病毒的 感染须做好防蚊灭虫等工作，做好个人防护，减少 与虫媒昆虫等的接触(Elliott, 2014)。

\section{幻影病毒科}

布尼亚病毒目中新定义的病毒科，也称幽蚊病 毒科，目前仅包含1个病毒属：正幻影病毒属 (Orthophasmavirus), 含有6个病毒种, 因其代表种 基格卢艾克幻影病毒 (Kigluaike phantom virus, KIGV)和另一病毒种诺姆幻影病毒(Nome phantom virus, NOMV)在北极幻影蚊中鉴定出而得名。其他4 个成员分别是：武汉蚊子正幻影病毒1 (Wuhan mosquito orthophasmavirus 1)、武汉蚊子正幻影病毒 2 (Wuhan mosquito orthophasmavirus 2)、武昌蟑螂正 幻影病毒1 (Wuchang cockroach orthophasmavirus 1) 和双忝昆虫正幻影病毒2 (Shuangao insect orthophasmavirus 2), 均因病毒种被鉴定出的宿主种类和 地点而命名(Ballinger et al, 2014; Junglen, 2016)。

目前, 尚未在体外成功分离到任何一种正幻影 病毒, 因此这类病毒的形态结构还不清楚。KIGV、 武汉蚊子正幻影病毒1、武汉蚊子正幻影病毒 2 和武 昌蟑螂正幻影病毒1均获得了完整的全长基因组序 列。正幻影病毒基因组由 $\mathrm{L} 、 M$ 和 $\mathrm{S}$ 三个RNA节段组 成。各病毒种三个片段的长度差异较大: L片段为 6.5-6.7 kb, 编码病毒RdRp; M片段为2.1-2.8 kb, 编 码 $\mathrm{Gn} 、 \mathrm{Gc} ; \mathrm{S}$ 片段为1.8-2.7 kb, 除编码NP外, 还可 能编码NSs (Ballinger et al, 2014; Li et al, 2015; Junglen, 
2016)。

正幻影病毒仅感染蚊(幽蚊科, 蚊科库蚊属)、 蟑螂(Blattodea)和尺蛾(Abraxas tenuisuffusa)等节肢 动物, 属于昆虫宿主限制性病毒, 在自然界中的传 播方式和稳定性还有待研究。

\section{白纤病毒科}

布尼亚病毒目中新定义的病毒科, 目前包含4 个病毒属, 分别是: 格克病毒属、帕西病毒属 (Phasivirus)、白蛉病毒属(Phlebovirus)和纤细病毒 属 (Tenuivirus)。白纤病毒科的拉丁文名称 Phenuiviridae是因白蛉病毒属Phlebovirus中的“Ph-” 和纤细病毒属Tenuivirus中“enui-”而得名。白纤病毒 科各属的病毒形态、感染宿主和基因组结构等特征 差异很大, 但其编码的 RdRp蛋白的遗传进化亲缘 关系较近，因此被分类到同一个病毒科。

格克病毒属包含 3 个病毒种, 其代表种 GOLV 分离自科特迪瓦一个叫格里克(Gouleako)的村庄采 集的蚊子中(Marklewitz et al, 2011)。另一病毒种一库 努托病毒(Cumuto virus)分离自科特迪瓦库托努村 (Cunuto)采集的蚊子(Auguste et al, 2014)。以库努托 病毒为代表, 格里克病毒粒子具有包膜包裹, 呈多 型性, 直径约为 $120 \mathrm{~nm}$ 。格里克病毒和库努托病毒 仅能感染蚊(库蚊属、按蚊属和蓝带蚊属), 尚未有感 染其他节肢动物或脊椎动物的报道, 这可能与它们 未编码NSm和NSs蛋白有关。近年报道的新成员宜 昌昆虫格克病毒(Yichang insect goukovirus)分离自 中国宜昌地区采集的蚜虫, 获得了基因组全序列, 但未分离培养得到活病毒(Li et al, 2015)。

帕西病毒属包含4个病毒种, 其代表种巴杜病 毒(Badu phasivirus, BADUV)分离自澳大利亚巴杜 岛(Badu)采集的库蚊, 病毒粒子具有典型的布尼亚 病毒形态，是具有包膜包裹的球形颗粒，直径约为 $130 \mathrm{~nm}$ (Hobson-Peters et al, 2016)。另一成员帕西乍 仑类病毒(Phasi Charoen-like phasivirus)是在泰国的 帕西乍仑采集的伊蚊中检测到的, 并未分离到活病 毒。由于发现帕西乍仑类病毒的时间先于巴杜病毒, 帕西病毒属以帕西乍仑类病毒而得名(Chandler et al, 2014)。近年报道的病毒成员武汉苍蝇病毒和五 台蚊子病毒是在中国采集的苍蝇和蚊子中通过宏 基因组鉴定得到的，同时获得了病毒的全基因组序 列(Li et al, 2015)。该属病毒可感染蚊(库蚊属和伊蚊
属)、苍蝇等节肢动物。目前尚未有帕西病毒属成员 感染脊椎动物的报道。

白蛉病毒属病毒都是虫媒病毒, 可通过白蛉、 蚊子、蜱和蠓等节肢动物传播, 感染多种哺乳动物 和人类, 严重威胁人类健康和经济发展。如代表种 里夫特裂谷热病毒(Rift Valley fever phlebovirus, RVFV)可感染饲养动物, 如牛、羊、骆驼等, 能通 过接触动物或蚊虫叮咬传染给人, 并导致发热、肌 肉关节疼痛和头痛等症状, 严重可出现脑膜炎、出 血热等症状(Pepin et al, 2010)。我国近年报道的重要 新发传染病一发热伴血小板减少综合征(SFTS phlebovirus), 也称(Severe fever with thrombocytopenia syndrome virus, SFTSV), 就是由一种白蛉病 毒属病毒SFTSV感染引起的, 主要是通过蜱虫叮咬 引起的一种“蜱虫病”。与大多数布尼亚病毒相同, 白蛉病毒属成员基因组包含 $\mathrm{L} 、 \mathrm{M}$ 和 $\mathrm{S}$ 三个RNA节段, 其中S片段采用双义编码策略分别编码NP和NSs。 部分病毒(如里夫特裂谷热病毒)的M片段编码 GP, 可剪切为 $\mathrm{Gn} 、 \mathrm{Gc}$ 和NSm。每个基因片段的 $5^{\prime}$ 和3'端 为保守的反向互补序列, 基因组为锅柄状结构, 与 病毒的正确包装相关。

纤细病毒属是一类植物病毒, 代表种为水稻条 纹叶枯病毒(Rice strip virus, RSV), 感染的植物多 为经济作物, 如水稻、玉米、小麦和菎等。该病毒 属病毒基因组包含 4-6个RNA节段，除水稻草状矮 化病毒RGSV的所有节段为双义RNA外, 其他病毒 的RNA-1为单义负链RNA，其余节段为双义RNA。 纤细病毒属病毒颗粒形态与其他的布尼亚病毒有 较大差异, 虽然它们都编码糖蛋白, 但形成的病毒 粒子无囊膜包裹，呈直径为3-8 $\mathrm{nm}$ 的丝状。该属病 毒能在植物细胞内扩增, 通过飞虫、叶蝉传播, 并 且能经卵垂直传播。昆虫感染纤细病毒后会出现产 卵率下降，寿命缩短等症状; 纤细病毒感染植物后 将出现萎黄条纹症状。

\section{番茄斑萎病毒科}

布尼亚病毒目中新定义的病毒科, 现确定 1 个 病毒属, 即正番茄斑萎病毒属(Orthotospovirus), 原 名番茄斑萎病毒属(Tospovirus)。该属下含11个病毒 种, 代表种为正番茄斑萎病毒(Tomato spotted wilt orthotospovirus), 原名番茄斑萎病毒(Tomato spotted wilt tospovirus), 该病毒最初于1919年在澳洲于番 
茄上分离到。番茄斑萎病毒科的拉丁文名称Tospoviridae是取自正番茄斑萎病毒属(Orthotospovirus) 中的“tospo-”而得名。该科病毒粒子为具有包膜的球 形, 直径80-120 nm, 表面具有5-10 nm的糖蛋白突 起, 纯化的病毒粒子有时出现尾巴状的挤出物。病 毒基因组由 $\mathrm{L} 、 \mathrm{M}$ 和 $\mathrm{S}$ 三个RNA节段组成，三个RNA 片段 3 未端 8 个核苷酸(UCUCGUUA) 高度保守 (Pappu et al, 2009)。M片段上的G1和G2糖蛋白与病 毒-介体的互作有关(Takeda et al, 2002; Oliveira et al, 2011)。

正番茄斑萎病毒为一种世界性分布的植物病 毒, 包括整个北半球, 其寄主范围很广, 包括温带、 亚热带和热带的 80 多个科 1,000 余种双子叶和单子 叶植物, 涉及粮食、烟草、蔬菜及花卉, 可引起许 多重要的园艺植物和经济农作物的严重病害, 而属 内其他病毒的寄主范围要窄得多(Bezerra et al, 1999; Adkins, 2000; Pappu et al, 2009; Smirnova et al, 2016)。

番茄斑萎病毒科病毒可以通过植物汁液进行 传播, 在寄主植株间的自然传播主要是通过昆虫媒 介蓟马, 根据文献报道, 自然界至少有 12 种蓟马可 以持久性传播该病毒, 包括烟蓟马(Thrips tabaci)、 苏花蓟马(Frankliniella schultzei)、苜宿蓟马(F. occidentalis)等。蓟马的若虫获毒, 成虫不能获毒, 但只 有成虫才能传毒, 媒介昆虫有的可以终生带毒, 属 持久性传毒, 但不能把病毒传给子代; 也有报道番 茄的种子可传播和携带病毒。该科病毒的传播媒介 一旦携带该病毒, 则终身带毒, 病毒能在媒介昆虫 体内循环增殖，以自行复制的方式提高传播效率。

植株被番茄斑萎病毒科病毒侵染后, 常见症状 为叶片产生黄化斑点、斑驳、㱟皱、萎凋甚至严重 坏疽等。由于该病毒具有糖蛋白包膜, 抗原性较弱, 制备抗血清较难。另外该病毒可在杂草上存活, 且 传播媒介蓟马的控制难度大, 因而在田间并无有效 措施防治该病毒。目前最有希望的是通过培育抗病 品种或采取生物防治等综合手段来防治。

\section{0 小结}

根据布尼亚病毒目各个科属中病毒代表成员 的RdRp的氨基酸序列, 构建最大相似度进化树 (图 1), 结果显示布尼亚病毒目 9 个病毒科和 13 个病毒 属都具有较好的进化聚类; 其中, 仅不经节肢动物
传播的汉坦病毒科的遗传进化关系与其他病毒科 相距明显较远，而其他病毒科的病毒都可经蜱、蚊 和蛉等媒介昆虫进行传播; 布尼亚病毒目中的番茄 斑萎病毒科、费莫病毒科以及白纤病毒科的纤细病 毒属的病毒均为植物病毒, 其他病毒的进化聚类和 遗传关系则与其宿主种类没有相关性。

布尼亚病毒目下属多个病毒科(属)的病毒对人 和动物具有烈性感染致病能力, 或者具有潜在的感 染致病风险。所以，广泛开展布尼亚病毒目下属的 病毒的研究, 对于系统揭示它们对人和动物的感染 致病能力以及由布尼亚病毒感染引起的传染病的 防控工作具有重要意义。

\section{参考文献}

Adkins S (2000) Tomato spotted wilt virus-positive steps towards negative success. Molecular Plant Pathology, 1, 151-157.

Arai S, Nguyen ST, Boldgiv B, Fukui D, Araki K, Dang CN, Ohdachi SD, Nguyen NX, Pham TD, Boldbaatar B, Satoh H, Yoshikawa Y, Morikawa S, Tanaka-Taya K, Yanagihara R, Oishi K (2013) Novel bat-borne hantavirus, Vietnam. Emerging Infectious Diseases, 19, 1159-1161.

Auguste AJ, Carrington CV, Forrester NL, Popov VL, Guzman H, Widen SG, Wood TG, Weaver SC, Tesh RB (2014) Characterization of a novel negevirus and a novel Bunyavirus isolated from Culex (Culex) declarator mosquitoes in Trinidad. Journal of General Virology, 95, 481-485.

Ballinger MJ, Bruenn JA, Hay J, Czechowski D, Taylor DJ (2014) Discovery and evolution of bunyavirids in arctic phantom midges and ancient bunyavirid-like sequences in insect genomes. Journal of Virology, 88, 8783-8794.

Bezerra IC, de Resende R, Pozzer L, Nagata T, Kormelink R, De Avila AC (1999) Increase of tospoviral diversity in Brazil with the identification of two new tospovirus species, one from chrysanthemum and one from zucchini. Phytopathology, 89, 823-830.

Carstens EB (2010) Ratification vote on taxonomic proposals to the International Committee on Taxonomy of Viruses (2009). Archives of Virology, 155, 133-146.

Chandler JA, Thongsripong P, Green A, Kittayapong P, Wilcox BA, Schroth GP, Kapan DD, Bennett SN (2014) Metagenomic shotgun sequencing of a Bunyavirus in wild-caught Aedes aegypti from Thailand informs the evolutionary and genomic history of the Phleboviruses. Virology, 464-465, 312-319.

Chung HC, Nguyen VG, Goede D, Park CH, Kim AR, Moon HJ, Park SJ, Kim HK, Park BK (2014) Gouleako and Herbert viruses in pigs, Republic of Korea, 2013. Emerging Infectious Diseases, 20, 2072-2075. 
Davies FG (1997) Nairobi sheep disease. Parassitologia, 39, 95-98.

Elbeaino T, Digiaro M, Alabdullah A, De Stradis A, Minafra A, Mielke N, Castellano MA, Martelli GP (2009a) A multipartite single-stranded negative-sense RNA virus is the putative agent of fig mosaic disease. Journal of General Virology, 90, 1281-1288.

Elbeaino T, Digiaro M, Martelli GP (2009b) Complete nucleotide sequence of four RNA segments of fig mosaic virus. Archives of Virology, 154, 1719-1727.

Elbeaino T, Digiaro M, Uppala M, Sudini H (2014) Deep sequencing of pigeonpea sterility mosaic virus discloses five RNA segments related to emaraviruses. Virus Research, 188, 27-31.

Elbeaino T, Digiaro M, Uppala M, Sudini H (2015) Addendum to: Deep-sequencing of dsRNAs recovered from mosaic-diseased pigeonpea reveals the presence of a novel emaravirus: Pigeonpea sterility mosaic virus 2. Archives of Virology, 160, 2031.

Elliott RM (2014) Orthobunyaviruses: Recent genetic and structural insights. Nature Reviews Microbiology, 12, 673-685.

Ergonul O (2006) Crimean-Congo haemorrhagic fever. Lancet Infectious Diseases, 6, 203-214.

Ergonul O (2012) Crimean-Congo hemorrhagic fever virus: New outbreaks, new discoveries. Current Opinion in Virology, 2, 215-220.

Fang Y, Wu GH, Tang JQ (2015) Overview of virus infection in Buniaviridae. In: Natural Focus Infection Disease (ed. Tang JQ), pp. 46-57. Science Press, Beijing. (in Chinese) [方元, 吴光华, 唐家琪 (2015) 布尼亚病毒科病毒感染 概述. 见: 自然疫源性疾病(唐家琪主编), 46-57页. 科学 出版社, 北京.]

Francki RIB, Fauquet CM, Knudson DL, Brown F (1991) Classification and nomenclature of viruses. Fifth Report of the International Committee on Taxonomy of Viruses Archives of Virology. Archives of Virology, 2, 273-283.

Gerrard SR, Nichol ST (2007) Synthesis, proteolytic processing and complex formation of N-terminally nested precursor proteins of the Rift Valley fever virus glycoproteins. Virology, 357, 124-133.

Golovljova I, Vasilenko V, Mittzenkov V, Prükk T, Seppet E, Vene S, Settergren B, Plyusnin A, Lundkvist A (2007) Characterization of hemorrhagic fever with renal syndrome caused by hantaviruses, Estonia. Emerging Infectious Diseases, 13, 1773-1776.

Guterres A, de Oliveira RC, Fernandes J, de Lemos ER, Schrago CG (2017) New bunya-like viruses: Highlighting their relations. Infection Genetics and Evolution, 49, 164-173.

Hobson-Peters J, Warrilow D, McLean BJ, Watterson D, Colmant AM, van den Hurk AF, Hall-Mendelin S, Hastie ML, Gorman JJ, Harrison JJ, Prow NA, Barnard RT, Allcock R,
Johansen CA, Hall RA (2016) Discovery and characterisation of a new insect-specific bunyavirus from Culex mosquitoes captured in northern Australia. Virology, 489, 269-281.

Ishikawa K, Maejima K, Komatsu K, Kitazawa Y, Hashimoto M, Takata D, Yamaji Y, Namba S (2012) Identification and characterization of two novel genomic RNA segments of fig mosaic virus, RNA5 and RNA6. Journal of General Virology, 93, 1612-1619.

Jiang H, Zheng X, Wang L, Du H, Wang P, Bai X (2017) Hantavirus infection: A global zoonotic challenge. Virologica Sinica, 32, 32-43.

Jonsson CB, Figueiredo LT, Vapalahti O (2010) A global perspective on hantavirus ecology, epidemiology, and disease. Clinical Microbiology Reviews, 23, 412-441.

Junglen S (2016) Evolutionary origin of pathogenic arthropod-borne viruses - a case study in the family Bunyaviridae. Current Opinion in Insect Science, 16, 81-86.

Junglen S, Kurth A, Kuehl H, Quan PL, Ellerbrok H, Pauli G, Nitsche A, Nunn C, Rich SM, Lipkin WI, Briese T, Leendertz FH (2009) Examining landscape factors influencing relative distribution of mosquito genera and frequency of virus infection. EcoHealth, 6, 239-249.

Junglen S, Marklewitz M, Zirkel F, Wollny R, Meyer B, Heidemann H, Metzger S, Annan A, Dei D, Leendertz FH, Oppong S, Drosten C (2015) No evidence of Gouléako and Herbert virus infections in pigs, Côte d'Ivoire and Ghana. Emerging Infectious Diseases, 21, 2190.

Khaiboullina SF, Morzunov SP, St Jeor SC (2005) Hantaviruses: Molecular biology, evolution and pathogenesis. Current Molecular Medicine, 5, 773-790.

King AMQ, Adams MJ, Carstens EB, Lefkowitz EJ (2011) Virus Taxonomy: Ninth Report of the International Committee on Taxonomy of Viruses. Elsevier Academic Press, London.

Korneyeva M, Hotta J, Lebing W, Rosenthal RS, Franks L, Petteway SR Jr (2002) Enveloped virus inactivation by caprylate: A robust alternative to solvent-detergent treatment in plasma derived intermediates. Biologicals, 30, 153-162.

Kuhn JH, Wiley MR, Rodriguez SE, Bào Y, Prieto K, Travassos da Rosa AP, Guzman H, Savji N, Ladner JT, Tesh RB, Wada J, Jahrling PB, Bente DA, Palacios G (2016) Genomic characterization of the genus Nairovirus (Family Bunyaviridae). Viruses, 8, 164.

Laney AG, Keller KE, Martin RR, Tzanetakis IE (2011) A discovery 70 years in the making: Characterization of the Rose rosette virus. Journal of General Virology, 92, 1727-1732.

Lee HW, Lee PW, Johnson KM (1978) Isolation of the etiologic agent of Korean Hemorrhagic fever. Journal of Infectious Diseases, 137, 298-308.

Lefkowitz EJ, Davison AJ, Sabanadzovic S, Siddell SG, Simmonds P (2017) Virus Taxonomy: The Classification and 
Nomenclature of Viruses, The Online (10th) Report of the ICTV (2017) Authority Files for International Committee on Taxonomy of Viruses. https://talk.ictvonline.org/ictv-reports /ictv_online_report/.

Li CX, Shi M, Tian JH, Lin XD, Kang YJ, Chen LJ, Qin XC, $\mathrm{Xu}$ J, Holmes EC, Zhang YZ (2015) Unprecedented genomic diversity of RNA viruses in arthropods reveals the ancestry of negative-sense RNA viruses. eLife, 4, e05378.

Marczinke BI, Nichol ST (2002) Nairobi sheep disease virus, an important tick-borne pathogen of sheep and goats in Africa, is also present in Asia. Virology, 303, 146-151.

Marklewitz M, Handrick S, Grasse W, Kurth A, Lukashev A, Drosten C, Ellerbrok H, Leendertz FH, Pauli G, Junglen S (2011) Gouleako virus isolated from West African mosquitoes constitutes a proposed novel genus in the family Bunyaviridae. Journal of Virology, 85, 9227-9234.

Marklewitz M, Zirkel F, Kurth A, Drosten C, Junglen S (2015) Evolutionary and phenotypic analysis of live virus isolates suggests arthropod origin of a pathogenic RNA virus family. Proceedings of the National Academy of Sciences, USA, 112, 7536-7541.

Marklewitz M, Zirkel F, Rwego IB, Heidemann H, Trippner P, Kurth A, Kallies R, Briese T, Lipkin WI, Drosten C, Gillespie TR, Junglen S (2013) Discovery of a unique novel clade of mosquito-associated bunyaviruses. Journal of Virology, 87, 12850-12865.

Mayo MA (2002a) Virus taxonomy-Houston 2002. Archives of Virology, 147, 1071-1076.

Mayo MA (2002b) A summary of taxonomic changes recently approved by ICTV. Archives of Virology, 147, 1655-1656.

McGavin WJ, Mitchell C, Cock PJ, Wright KM, MacFarlane SA (2012) Raspberry leaf blotch virus, a putative new member of the genus Emaravirus, encodes a novel genomic RNA. Journal of General Virology, 93, 430-437.

Mielke N, Muehlbach HP (2007) A novel, multipartite, negative-strand RNA virus is associated with the ringspot disease of European mountain ash (Sorbus aucuparia L.). Journal of General Virology, 88, 1337-1346.

Mir MA, Panganiban AT (2005) The hantavirus nucleocapsid protein recognizes specific features of the viral RNA panhandle and is altered in conformation upon RNA binding. Journal of Virology, 79, 1824-1835.

Oliveira VC, Bartasson L, de Castro ME, Corrêa JR, Ribeiro BM, Resende RO (2011) A silencing suppressor protein (NSs) of a tospovirus enhances baculovirus replication in permissive and semipermissive insect cell lines. Virus Research, 155, 259-267.

Pappu HR, Jones RA, Jain RK (2009) Global status of tospovirus epidemics in diverse cropping systems: Successes achieved and challenges ahead. Virus Research, 141, 219-236.

Pepin M, Bouloy M, Bird BH, Kemp A, Paweska J (2010) Rift Valley fever virus (Bunyaviridae: Phlebovirus): An update on pathogenesis, molecular epidemiology, vectors, diagnostics and prevention. Veterinary Research, 41, 61.

Plyusnin A, Beaty BJ, Elliott RM, Goldbach R, Kormelink R, Lundkvist A, Schmaljohn CS, Tesh RB (2011) Family Bunyaviridae. In: Virus Taxonomy Ninth Report of the International Committee on Taxonomy of Viruses (eds King AMQ, Adams MJ, Carstens EB, Lefkowitz EJ), pp. 725-741. Elsevier/Academic Press, London.

Pringle CR (1993) Virus taxonomy update. Taxonomic decisions ratified at the plenary meeting of the ICTV at the 9th international congress of virology held in Glasgow on the 10th August 1993. Archives of Virology, 133, 491-495.

Scholz S, Baharom F, Rankin G, Maleki KT, Gupta S, Vangeti S, Pourazar J, Discacciati A, Höijer J, Bottai M, Björkström NK, Rasmuson J, Evander M, Blomberg A, Ljunggren HG, Klingström J, Ahlm C, Smed-Sörensen A (2017) Human hantavirus infection elicits pronounced redistribution of mononuclear phagocytes in peripheral blood and airways. PLoS Pathog, 13, 1-24.

Skare JM, Wijkamp I, Denham I, Rezende JA, Kitajima EW, Park JW, Desvoyes B, Rush CM, Michels G, Scholthof KB, Scholthof HB (2006) A new eriophyid mite-borne membrane-enveloped virus-like complex isolated from plants. Virology, 347, 343-353.

Smirnova IP, Shneider YA, Karimova EV (2016) Trichoderma L-lysine-alpha-Oxidase producer strain culture fluid inhibits impatiens necrotic spot virus. Bulletin of Experimental Biology and Medicine, 160, 357-359.

Takeda A, Sugiyama K, Nagano H, Mori M, Kaido M, Mise K, Tsuda S, Okuno T (2002) Identification of a novel RNA silencing suppressor, NSs protein of tomato spotted wilt virus. FEBS Letters, 532, 75-79.

Tatineni S, McMechan AJ, Wosula EN, Wegulo SN, Graybosch RA, French R, Hein GL (2014) An eriophyid mite-transmitted plant virus contains eight genomic RNA segments with unusual heterogeneity in the nucleocapsid protein. Journal of Virology, 88, 11834-11845.

Tokarz R, Williams SH, Sameroff S, Sanchez Leon M, Jain K, Lipkin WI (2014) Virome analysis of Amblyomma americanum, Dermacentor variabilis, and Ixodes scapularis ticks reveals novel highly divergent vertebrate and invertebrate viruses. Journal of Virology, 88, 11480-11492.

Walker PJ, Widen SG, Firth C, Blasdell KR, Wood TG, Travassos da Rosa AP, Guzman H, Tesh RB, Vasilakis N (2015) Genomic characterization of Yogue, Kasokero, Issyk-Kul, Keterah, Gossas, and Thiafora viruses: Nairoviruses naturally infecting bats, shrews, and ticks. American Journal of Tropical Medicine and Hygiene, 93, 1041-1051.

Witkowski PT, Drexler JF, Kallies R, Ličková M, Bokorová S, Mananga GD, Szemes T, Leroy EM, Krüger DH, Drosten C, Klempa B (2016) Phylogenetic analysis of a newfound bat-borne hantavirus supports a laurasiatherian host association for ancestral mammalian hantaviruses. Infection Genetics 
and Evolution, 41, 113-119.

Won S, Ikegami T, Peters CJ, Makino S (2006) NSm and 78-kilodalton proteins of Rift Valley fever virus are nonessential for viral replication in cell culture. Journal of Virology, 80, 8274-8278.

Yu XJ, Tesh RB (2014) The role of mites in the transmission and maintenance of Hantaan virus (Hantavirus: Bunyaviridae). Journal of Infectious Diseases, 210, 1693-1699.

Zhang YZ (2014) Discovery of hantaviruses in bats and insectivores and the evolution of the genus Hantavirus. Virus Research, 187, 15-21.

Zheng YZ, Navarro B, Wang GP, Wang YX, Yang ZK, Xu
WX, Zhu CX, Wang LP, Serio FD, Hong N (2017) Actinidia chlorotic ringspot-associated virus: A novel emaravirus infecting kiwifruit plants. Molecular Plant Pathology, 18, 569-581.

Zhu J, Zhang Y, Wu GH (2015) Crimean-Congo hemorrhagic fever. In: Natural Focus Infection Disease (ed. Tang JQ), pp. 108-131. Science Press, Beijing. (in Chinese) [朱进, 张云, 吴光华 (2015) 克里米亚-刚果出血热. 见: 自然疫源性 疾病(唐家琪主编), 108-131页. 科学出版社, 北京.]

(责任编委：张全国 责任编辑：时意专)

\section{附录 Supplementary Material}

附录1 布尼亚病毒目各科病毒基本信息汇总

Appendix 1 Basic information of all families for Bunyavirales

http://www.biodiversity-science.net/fileup/PDF/2018042-1.pdf

附录 2 布尼亚病毒缩写和 L 片段序列号

Appendix 2 Bunyavirus abbreviations and L segment accession numbers

http://www.biodiversity-science.net/fileup/PDF/2018042-2.pdf 
唐霜, 沈姝, 史君明, 方耀辉, 王华林, 胡志红, 邓菲. 布尼亚病毒目新分类概述. 生物多样性, 2018, 26 (9): 1004-1015.

http://www.biodiversity-science.net/CN/10.17520/biods.2018042

附录1 布尼亚病毒目各科病毒基本信息汇总

Appendix 1 Basic information of all families for Bunyavirales

\begin{tabular}{|c|c|c|c|c|c|c|c|}
\hline $\begin{array}{l}\text { 科 } \\
\text { Family }\end{array}$ & $\begin{array}{l}\text { 属 } \\
\text { Genus }\end{array}$ & $\begin{array}{l}\text { 代表种 } \\
\text { Typical species }\end{array}$ & $\begin{array}{l}\text { 病毒形态 } \\
\text { Virion morphology }\end{array}$ & $\begin{array}{l}\text { 基因组结构 } \\
\text { Genome structure }\end{array}$ & $\begin{array}{l}\text { 编码蛋白 } \\
\text { Encoded } \\
\text { protein }\end{array}$ & $\begin{array}{l}\text { 主要传播媒介a } \\
\text { Primary vector }\end{array}$ & $\begin{array}{l}\text { 感染宿主 }^{a} \\
\text { Host }\end{array}$ \\
\hline $\begin{array}{l}\text { 费拉病毒科 } \\
\text { Feraviridae }\end{array}$ & $\begin{array}{l}\text { 正费拉病毒属 } \\
\text { Orthoferavirus }\end{array}$ & $\begin{array}{l}\text { 费拉克正费拉病毒 } \\
\text { Ferak orthoferavirus }\end{array}$ & $\begin{array}{l}\text { 有囊膜 } \\
\text { 多形性球形 } \\
\text { 直径60-120 nm } \\
\text { Enveloped } \\
\text { Pleomorphic sphere } \\
60-120 \mathrm{~nm} \text { in diameter }\end{array}$ & $\begin{array}{l}\text { 单链负义三节段: } \\
\text { L: } 6.9 \mathrm{~kb} \\
\text { M: } 4.3 \mathrm{~kb} \\
\text { S: } 1.5 \mathrm{~kb} \\
\text { Tri-segmented genome of negative } \\
\text { sense single-stranded RNA: } \\
\text { L: } 6.9 \mathrm{~kb} \\
\text { M: } 4.3 \mathrm{~kb} \\
\text { S: } 1.5 \mathrm{~kb}\end{array}$ & $\begin{array}{l}\text { L: RdRp } \\
\text { M: GP (Gn, Gc, } \\
\text { NSm) } \\
\text { S: NP, NSs }\end{array}$ & - & $\begin{array}{l}\text { 蚊、水黾 } \\
\text { Culex, Anopheles, Uranotaenia; } \\
\text { Water strider }\end{array}$ \\
\hline $\begin{array}{l}\text { 无花果叶病毒科 } \\
\text { Fimoviridae }\end{array}$ & $\begin{array}{l}\text { 伊马拉病毒属 } \\
\text { Emaravirus }\end{array}$ & $\begin{array}{l}\text { 欧洲花楸环斑病相关病毒 } \\
\text { European mountain ash ringspot- } \\
\text { associated virus }\end{array}$ & $\begin{array}{l}\text { 有囊膜 } \\
\text { 球形 } \\
\text { 直径80-200 nm } \\
\text { Enveloped } \\
\text { Spherical virion } \\
\text { 80-200 nm in diameter }\end{array}$ & $\begin{array}{l}\text { 单链负义4-8节段: } \\
\text { RNA1: } 7.0-7.1 \mathrm{~kb} \\
\text { RNA2: } 2.1-2.3 \mathrm{~kb} \\
\text { RNA3: } 0.9-1.7 \mathrm{~kb} \\
\text { RNA4: } 1.1-1.7 \mathrm{~kb} \\
\text { RNA5: } 1.5-1.8 \mathrm{~kb} \\
\text { RNA6: } 1.1-1.8 \mathrm{~kb} \\
\text { RNA7: } 1.1-1.6 \mathrm{~kb} \\
\text { RNA8: 约1.3 kb } \\
\text { Four - eight segmented genome of } \\
\text { negative sense single-stranded RNA: } \\
\text { RNA1: } 7.0-7.1 \mathrm{~kb} \\
\text { RNA2: } 2.1-2.3 \mathrm{~kb} \\
\text { RNA3: } 0.9-1.7 \mathrm{~kb} \\
\text { RNA4: } 1.1-1.7 \mathrm{~kb} \\
\text { RNA5: } 1.5-1.8 \mathrm{~kb} \\
\text { RNA6: } 1.1-1.8 \mathrm{~kb} \\
\text { RNA7: } 1.1-1.6 \mathrm{~kb} \\
\text { RNA8: About } 1.3 \mathrm{~kb}\end{array}$ & $\begin{array}{l}\text { RNA-1: RdRp } \\
\text { RNA-2: GP } \\
\text { RNA-3: NP } \\
\text { 其他基因节段编 } \\
\text { 码的蛋白的生物 } \\
\text { 学功能尚不明确 } \\
\text { RNA-1: RdRp } \\
\text { RNA-2: GP } \\
\text { RNA-3: NP } \\
\text { The biological } \\
\text { function of the } \\
\text { proteins encoded } \\
\text { in other gene } \\
\text { segments are not } \\
\text { yet clear }\end{array}$ & $\begin{array}{l}\text { 螨 } \\
\text { Aceria, Phytoptus, } \\
\text { Phyllocoptes }\end{array}$ & $\begin{array}{l}\text { 植物 } \\
\text { Plants }\end{array}$ \\
\hline
\end{tabular}


唐霜，沈姝，史君明，方耀辉，王华林，胡志红，邓菲. 布尼亚病毒目新分类概述. 生物多样性, 2018, 26 (9): 1004-1015.

http://www.biodiversity-science.net/CN/10.17520/biods.2018042

\begin{tabular}{|c|c|c|c|c|c|c|c|}
\hline $\begin{array}{l}\text { 科 } \\
\text { Family }\end{array}$ & $\begin{array}{l}\text { 属 } \\
\text { Genus }\end{array}$ & $\begin{array}{l}\text { 代表种 } \\
\text { Typical species }\end{array}$ & $\begin{array}{l}\text { 病毒形态 } \\
\text { Virion morphology }\end{array}$ & $\begin{array}{l}\text { 基因组结构 } \\
\text { Genome structure }\end{array}$ & $\begin{array}{l}\text { 编码蛋白 } \\
\text { Encoded } \\
\text { protein }\end{array}$ & $\begin{array}{l}\text { 主要传播媒介 }^{\mathrm{a}} \\
\text { Primary vector }\end{array}$ & $\begin{array}{l}\text { 感染宿主 }^{a} \\
\text { Host }\end{array}$ \\
\hline $\begin{array}{l}\text { 汉坦病毒科 } \\
\text { Hantaviridae }\end{array}$ & $\begin{array}{l}\text { 正汉坦病毒属 } \\
\text { Orthohantavirus }\end{array}$ & $\begin{array}{l}\text { 正汉坦病毒 } \\
\text { Hantaan orthohantavirus }\end{array}$ & $\begin{array}{l}\text { 有囊膜 } \\
\text { 球形 } \\
\text { 直径80-210 nm } \\
\text { Enveloped } \\
\text { Spherical virion } \\
80-210 \mathrm{~nm} \text { in diameter }\end{array}$ & $\begin{array}{l}\text { 单链负义三节段: } \\
\text { L: } 1.5-6.6 \mathrm{~kb} \\
\text { M: } 1.5-3.9 \mathrm{~kb} \\
\text { S: } 1.3-2.1 \mathrm{~kb} \\
\text { Tri-segmented genome of negative } \\
\text { sense single-stranded RNA: } \\
\text { L: } 1.5-6.6 \mathrm{~kb} \\
\text { M: } 1.5-3.9 \mathrm{~kb} \\
\text { S: } 1.3-2.1 \mathrm{~kb}\end{array}$ & $\begin{array}{l}\text { L: RdRp } \\
\text { M: GP(Gn, } \\
\text { Gc) } \\
\text { S: NP }\end{array}$ & $\begin{array}{l}\text { 螨、蚤 } \\
\text { Laelapinae, } \\
\text { Trombiculidae; } \\
\text { Xenopsylla, } \\
\text { Leptopsylla }\end{array}$ & $\begin{array}{l}\text { 主要感染啮齿类、食虫类动物; } \\
\text { 可感染哺乳类、鸟类、爬行类、 } \\
\text { 两栖类等上百种脊椎动物; 人 } \\
\text { Mainly infect rodents and } \\
\text { insectivores; hundreds of } \\
\text { vertebrates such as mammals, } \\
\text { birds, reptiles and amphibians; } \\
\text { Human }\end{array}$ \\
\hline $\begin{array}{l}\text { 米卡多病毒科 } \\
\text { Jonviridae }\end{array}$ & $\begin{array}{l}\text { 正米卡多病毒属 } \\
\text { Orthojonvirus }\end{array}$ & $\begin{array}{l}\text { 约赫特正米卡多病毒 } \\
\text { Jonchet orthojonvirus }\end{array}$ & $\begin{array}{l}\text { 有囊膜 } \\
\text { 呈两种不同的形态: } \\
\text { (1)直径约 } 80 \mathrm{~nm} \text { 的球形颗粒; } \\
\text { (2)直径约 } 60 \mathrm{~nm} \text { 、 } \\
\text { 长度约 } 600 \mathrm{~nm} \text { 的 } \\
\text { 杆状颗粒 } \\
\text { Enveloped } \\
\text { There are two } \\
\text { different forms: } \\
\text { (1) Spherical virions } \\
\text { of about } 80 \mathrm{~nm} \text { in diameter ; } \\
\text { (2) Rod-shaped virions of } \\
\text { about } 80 \mathrm{~nm} \text { in diameter and } \\
\text { about } 600 \mathrm{~nm} \text { in length }\end{array}$ & $\begin{array}{l}\text { 单链负义三节段: } \\
\text { L: } 6.9 \mathrm{~kb} \\
\text { M: } 5.4 \mathrm{~kb} \\
\text { S: } 1.7 \mathrm{~kb} \\
\text { Tri-segmented genome of negative } \\
\text { sense single-stranded RNA: } \\
\text { L: } 6.9 \mathrm{~kb} \\
\text { M: } 5.4 \mathrm{~kb} \\
\text { S: } 1.7 \mathrm{~kb}\end{array}$ & $\begin{array}{l}\text { L: RdRp } \\
\text { M: GP (Gn, } \\
\text { Gc, NSm) } \\
\text { S: NP, NSs }\end{array}$ & - & $\begin{array}{l}\text { 蚊 } \\
\text { Culex }^{\mathrm{a}}\end{array}$ \\
\hline $\begin{array}{l}\text { 内罗病毒科 } \\
\text { Nairoviridae }\end{array}$ & $\begin{array}{l}\text { 正内罗病毒属 } \\
\text { Orthonairovirus }\end{array}$ & $\begin{array}{l}\text { 正杜贝病毒 } \\
\text { Dugbe orthonairovirus }\end{array}$ & $\begin{array}{l}\text { 有囊膜 } \\
\text { 球形 } \\
\text { 直径80-120 nm } \\
\text { Enveloped } \\
\text { Spherical virion } \\
80-120 \mathrm{~nm} \text { in diameter }\end{array}$ & $\begin{array}{l}\text { 单链负义三节段: } \\
\text { L: } 11.7-12.3 \mathrm{~kb} \\
\text { M: } 4.0-5.4 \mathrm{~kb} \\
\text { S: } 1.5-2.3 \mathrm{~kb} \text { Tri-segmented geno- } \\
\text { me of negative sense } \\
\text { single-stranded RNA: } \\
\text { L: } 11.7-12.3 \mathrm{~kb} \\
\text { M: } 4.0-5.4 \mathrm{~kb} \\
\text { S: } 1.5-2.3 \mathrm{~kb}\end{array}$ & $\begin{array}{l}\text { L: RdRp } \\
\text { M: GP (Gn, } \\
\text { Gc) } \\
\text { S: NP }\end{array}$ & $\begin{array}{l}\text { 蜱、蚊、蠓(库蠓 } \\
\text { 属)、風子 } \\
\text { Ticks (Ixodidae, } \\
\text { Argasidae), } \\
\text { Mosquitoes, } \\
\text { biting midges } \\
\text { (culicoides), lice }\end{array}$ & $\begin{array}{l}\text { 啮齿类动物、蝙蝠、鸟、家畜 } \\
\text { 及野生动物; 人 } \\
\text { Rodents, bats, birds, livestock } \\
\text { and wildlife; Human }\end{array}$ \\
\hline
\end{tabular}


唐霜, 沈姝, 史君明, 方耀辉, 王华林, 胡志红, 邓菲. 布尼亚病毒目新分类概述. 生物多样性, 2018, 26 (9): 1004-1015.

http://www.biodiversity-science.net/CN/10.17520/biods.2018042

\begin{tabular}{|c|c|c|c|c|c|c|c|}
\hline $\begin{array}{l}\text { 科 } \\
\text { Family }\end{array}$ & $\begin{array}{l}\text { 属 } \\
\text { Genus }\end{array}$ & $\begin{array}{l}\text { 代表种 } \\
\text { Type Species }\end{array}$ & $\begin{array}{l}\text { 病毒形态 } \\
\text { Virion morphology }\end{array}$ & $\begin{array}{l}\text { 基因组结构 } \\
\text { Genome structure }\end{array}$ & $\begin{array}{l}\text { 编码蛋白 } \\
\text { Encoded } \\
\text { protein }\end{array}$ & 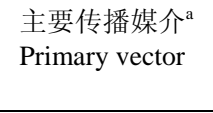 & $\begin{array}{l}\text { 感染宿主 }^{a} \\
\text { Host }\end{array}$ \\
\hline \multirow[t]{2}{*}{$\begin{array}{l}\text { 泛布尼亚病毒科 } \\
\text { Peribunyaviridae }\end{array}$} & $\begin{array}{l}\text { 赫伯病毒属 } \\
\text { Herbevirus }\end{array}$ & $\begin{array}{l}\text { 赫伯特病毒 } \\
\text { Herbert herbevirus }\end{array}$ & $\begin{array}{l}\text { 有囊膜 } \\
\text { 球形 } \\
\text { 直径90-110 nm } \\
\text { Enveloped } \\
\text { Spherical virion } \\
90-110 \mathrm{~nm} \text { in diameter }\end{array}$ & $\begin{array}{l}\text { 单链负义三节段: } \\
\text { L: } 7.3-7.5 \mathrm{~kb} \\
\text { M: } 2.6-4.8 \mathrm{~kb} \\
\text { S: } 1.1-1.2 \mathrm{~kb} \\
\text { Tri-segmented genome of negative } \\
\text { sense single-stranded RNA: } \\
\text { L: } 7.3-7.5 \mathrm{~kb} \\
\text { M: } 2.6-4.8 \mathrm{~kb} \\
\text { S: } 1.1-1.2 \mathrm{~kb}\end{array}$ & $\begin{array}{l}\text { L: RdRp } \\
\text { M: GP (Gn, } \\
\text { Gc) }{ }^{\mathrm{c}} \\
\text { S: NP }\end{array}$ & - & $\begin{array}{l}\text { 蚊 } \\
\text { Culex, Anopheles, } \\
\text { Uranotaenia,Culicidae. spp }{ }^{\mathrm{a}}\end{array}$ \\
\hline & $\begin{array}{l}\text { 正布尼亚病毒属 } \\
\text { Orthobunyavirus }\end{array}$ & $\begin{array}{l}\text { 正布尼亚韦拉病毒 } \\
\text { Bunyamwera orthobunyavirus }\end{array}$ & $\begin{array}{l}\text { 有囊膜 } \\
\text { 多形性球形 } \\
\text { 直径 } 108 \pm 8 \mathrm{~nm} \\
\text { Enveloped } \\
\text { Pleomorphic sphere } \\
108 \pm 8 \mathrm{~nm} \text { in diameter }\end{array}$ & $\begin{array}{l}\text { 单链负义三节段: } \\
\text { L: } 6.8-7.0 \mathrm{~kb} \\
\text { M: } 3.4-5.1 \mathrm{~kb} \\
\text { S: } 0.7-1.1 \mathrm{~kb} \\
\text { Tri-segmented genome of negative } \\
\text { sense single-stranded RNA: } \\
\text { L: } 6.8-7.0 \mathrm{~kb} \\
\text { M: } 3.4-5.1 \mathrm{~kb} \\
\text { S: } 0.7-1.1 \mathrm{~kb}\end{array}$ & $\begin{array}{l}\text { L: RdRp } \\
\text { M:GP(Gn, } \\
\text { NSm, Gc) } \\
\text { S: NP, NSs }\end{array}$ & $\begin{array}{l}\text { 蚊、蜱、床虫、 } \\
\text { 蠓 } \\
\text { Mosquitoes, } \\
\text { ticks, bedbugs, } \\
\text { midges }\end{array}$ & $\begin{array}{l}\text { 羊、牛、马等反刍动物; 人 } \\
\text { Ruminants such as sheep, cattle } \\
\text { and horses; Homo Sapiens }\end{array}$ \\
\hline $\begin{array}{l}\text { 幻影病毒科 } \\
\text { Phasmaviridae }\end{array}$ & $\begin{array}{l}\text { 正幻影病毒属 } \\
\text { Orthophasmavirus }\end{array}$ & $\begin{array}{l}\text { 基格卢艾克幻影病毒 } \\
\text { Kigluaike phantom virus }\end{array}$ & $\begin{array}{l}\text { 尚不清楚 } \\
\text { Unknown }\end{array}$ & $\begin{array}{l}\text { 单链负义三节段: } \\
\text { L: } 6.5-6.7 \mathrm{~kb} \\
\text { M: } 2.1-2.8 \mathrm{~kb} \\
\text { S: } 1.8-2.7 \mathrm{~kb} \\
\text { Tri-segmented genome of negative } \\
\text { sense single-stranded RNA: } \\
\text { L: } 6.5-6.7 \mathrm{~kb} \\
\text { M: } 2.1-2.8 \mathrm{~kb} \\
\text { S: } 1.8-2.7 \mathrm{~kb}\end{array}$ & $\begin{array}{l}\text { L: RdRp } \\
\text { M: GP, Gn, } \\
\text { Gc } \\
\text { S: NP, NSs }\end{array}$ & - & $\begin{array}{l}\text { 幻影蚊、蚊、蟑螂、尺蛾等节 } \\
\text { 肢动物 }^{\mathrm{a}} \\
\text { Arthropods such as }_{\text {Chaoboridae, Culex, }} \\
\text { cockroach, Abraxas } \\
\text { tenuisuffusa }^{\mathrm{a}}\end{array}$ \\
\hline $\begin{array}{l}\text { 白纤病毒科 } \\
\text { Phenuiviridae }\end{array}$ & $\begin{array}{l}\text { 格克病毒属 } \\
\text { Goukovirus }\end{array}$ & $\begin{array}{l}\text { 格里克病毒 } \\
\text { Gouleako goukovirus }\end{array}$ & $\begin{array}{l}\text { 有囊膜 } \\
\text { 多形性球形 } \\
\text { 直径约120 nm } \\
\text { Enveloped } \\
\text { Pleomorphic sphere } \\
120 \mathrm{~nm} \text { in diameter }\end{array}$ & $\begin{array}{l}\text { 单链负义三节段: } \\
\text { L: About } 6.4 \mathrm{~kb} \\
\text { M: } 3.2-3.3 \mathrm{~kb} \\
\text { S: } 1.0-1.2 \mathrm{~kb} \\
\text { Tri-segmented genome of negative } \\
\text { sense single-stranded RNA: } \\
\text { L: 约6.4 kb } \\
\text { M: } 3.2-3.3 \mathrm{~kb} \\
\text { S: } 1.0-1.2 \mathrm{~kb}\end{array}$ & $\begin{array}{l}\text { L: RdRp } \\
\text { M: GP (Gn, } \\
\text { Gc) } \\
\text { S: NP }\end{array}$ & - & $\begin{array}{l}\text { 蚊 } \\
\text { Culex, Anopheles, Uranotaenia }\end{array}$ \\
\hline
\end{tabular}


唐霜, 沈姝, 史君明, 方耀辉, 王华林, 胡志红, 邓菲. 布尼亚病毒目新分类概述. 生物多样性, 2018, 26 (9): 1004-1015.

http://www.biodiversity-science.net/CN/10.17520/biods.2018042

\begin{tabular}{|c|c|c|c|c|c|c|c|}
\hline $\begin{array}{l}\text { 科 } \\
\text { Family }\end{array}$ & $\begin{array}{l}\text { 属 } \\
\text { Genus }\end{array}$ & $\begin{array}{l}\text { 代表种 } \\
\text { Type Species }\end{array}$ & $\begin{array}{l}\text { 病毒形态 } \\
\text { Virion morphology }\end{array}$ & $\begin{array}{l}\text { 基因组结构 } \\
\text { Genome structure }\end{array}$ & $\begin{array}{l}\text { 编码蛋白 } \\
\text { Encoded } \\
\text { protein }\end{array}$ & $\begin{array}{l}\text { 主要传播媒介 }^{a} \\
\text { Primary vector }\end{array}$ & $\begin{array}{l}\text { 感染宿主 }^{a} \\
\text { Host }\end{array}$ \\
\hline & $\begin{array}{l}\text { 帕西病毒属 } \\
\text { Phasivirus }\end{array}$ & $\begin{array}{l}\text { 巴杜病毒 } \\
\text { Badu phasivirus }\end{array}$ & $\begin{array}{l}\text { 有囊膜 } \\
\text { 球形 } \\
\text { 直径约 } 130 \mathrm{~nm} \\
\text { Enveloped } \\
\text { Spherical virion } \\
130 \mathrm{~nm} \text { in diameter }\end{array}$ & $\begin{array}{l}\text { 单链负义三节段: } \\
\text { L: } 6.8-6.9 \mathrm{~kb} \\
\text { M: } 3.4-4.5 \mathrm{~kb} \\
\text { S: } 1.1-1.5 \mathrm{~kb} \\
\text { Tri-segmented genome of negative } \\
\text { sense single-stranded RNA: } \\
\text { L: } 6.8-6.9 \mathrm{~kb} \\
\text { M: } 3.4-4.5 \mathrm{~kb} \\
\text { S: } 1.1-1.5 \mathrm{~kb}\end{array}$ & $\begin{array}{l}\text { L: RdRp } \\
\text { M: Gc, Gn } \\
\text { S: NP }\end{array}$ & - & $\begin{array}{l}\text { 蚊、苍䗉等节肢 } \\
\text { 动物 } \\
\text { Culex, Aedes, fly }{ }^{\mathrm{a}}\end{array}$ \\
\hline & $\begin{array}{l}\text { 白蛉病毒属 } \\
\text { Phlebovirus }\end{array}$ & $\begin{array}{l}\text { 里夫特裂谷热病毒 } \\
\text { Rift Valley fever phlebovirus }\end{array}$ & $\begin{array}{l}\text { 有囊膜 } \\
\text { 球形 } \\
\text { 直径80-120 nm } \\
\text { Enveloped } \\
\text { Spherical virion } \\
80-120 \mathrm{~nm} \text { in diameter }\end{array}$ & $\begin{array}{l}\text { 单链负义三节段: } \\
\text { L: } 6.3-6.6 \mathrm{~kb} \\
\text { M: } 3.2-4.7 \mathrm{~kb} \\
\text { S: } 1.7-2.0 \mathrm{~kb} \\
\text { Tri-segmented genome of negative } \\
\text { sense single-stranded RNA: } \\
\text { L: } 6.3-6.6 \mathrm{~kb} \\
\text { M: } 3.2-4.7 \mathrm{~kb} \\
\text { S: } 1.7-2.0 \mathrm{~kb}\end{array}$ & $\begin{array}{l}\text { L: RdRp } \\
\text { M: GP (Gn, } \\
\text { Gc, NSm) }{ }^{\text {e; }} \\
\text { S: NP, NSs }\end{array}$ & $\begin{array}{l}\text { 白蛉, 蚊, 蜱, } \\
\text { 蠓 } \\
\text { Sandflies, } \\
\text { mosquitoes, } \\
\text { ticks and midges }\end{array}$ & \\
\hline & $\begin{array}{l}\text { 纤细病毒属 }^{\mathrm{d}} \\
\text { Tenuivirus }\end{array}$ & $\begin{array}{l}\text { 水稻条纹叶枯病毒 } \\
\text { Rice stripe tenuivirus }\end{array}$ & $\begin{array}{l}\text { 无囊膜 } \\
\text { 细丝状, 螺旋状、分枝状或环状 } \\
\text { 直径3-8 nm } \\
\text { Non-enveloped } \\
\text { Filamentous, spiral, branched or } \\
\text { looped } \\
\text { 3-8 nm in diameter }\end{array}$ & $\begin{array}{l}\text { 单链负义4-6节段RNA, 其中RNA-1 } \\
\text { 为单义负链RNA, 其余节段为双义 } \\
\text { RNA。 } \\
\text { RNA1: } 9.0-9.8 \mathrm{~kb} \\
\text { RNA2: } 3.1-4.1 \mathrm{~kb} \\
\text { RNA3: } 2.2-3.1 \mathrm{~kb} \\
\text { RNA4: } 2.0-2.9 \mathrm{~kb} \\
\text { RNA5: } 1.3-2.7 \mathrm{~kb} \\
\text { RNA6: 约2.6 kb } \\
\text { Four to six segmented genome of } \\
\text { negative sense single-stranded RNA, } \\
\text { in which RNA-1 is a negative sense } \\
\text { single-stranded RNA, and the } \\
\text { remaining segments are ambisense } \\
\text { RNA: } \\
\text { RNA1: } 9.0-9.8 \mathrm{~kb} \\
\text { RNA2: } 3.1-4.1 \mathrm{~kb} \\
\text { RNA3: } 2.2-3.1 \mathrm{~kb} \\
\text { RNA4: } 2.0-2.9 \mathrm{~kb} \\
\text { RNA5: } 1.3-2.7 \mathrm{~kb} \\
\text { RNA6: About } 2.6 \mathrm{~kb}\end{array}$ & $\begin{array}{l}\text { RNA1: RdRp (也 } \\
\text { 称作Pc1) } \\
\text { RNA2: NS2, } \\
\text { NSvc2 (也称作P2, } \\
\text { Pc2) } \\
\text { RNA3: NS3, CP } \\
\text { (也称作NS3, } \\
\text { NSvc3; P3, Pc3) } \\
\text { RNA4: SP, MP } \\
\text { (也称作NS4, } \\
\text { NSvc4; P4, Pc4) } \\
\text { RNA5: P5, Pc5 } \\
\text { RNA6: P6, Pc6 }\end{array}$ & $\begin{array}{l}\text { 飞虫, 叶蝉 } \\
\text { Delphacidae, } \\
\text { Cicadellidae }\end{array}$ & $\begin{array}{l}\text { 水稻、玉米、小麦、菼等多种植 } \\
\text { 物, 主要为禾本科植物; 昆虫 } \\
\text { Rice, corn, wheat, alfalfa and other } \\
\text { plants, mainly grasses; insects }\end{array}$ \\
\hline
\end{tabular}


唐霜, 沈姝, 史君明, 方耀辉, 王华林, 胡志红, 邓菲. 布尼亚病毒目新分类概述. 生物多样性, 2018, 26 (9): 1004-1015.

http://www.biodiversity-science.net/CN/10.17520/biods.2018042

\begin{tabular}{|c|c|c|c|c|c|c|c|}
\hline $\begin{array}{l}\text { 科 } \\
\text { Family }\end{array}$ & $\begin{array}{l}\text { 属 } \\
\text { Genus }\end{array}$ & $\begin{array}{l}\text { 代表种 } \\
\text { Type Species }\end{array}$ & $\begin{array}{l}\text { 病毒形态 } \\
\text { Virion morphology }\end{array}$ & $\begin{array}{l}\text { 基因组结构 } \\
\text { Genome structure }\end{array}$ & $\begin{array}{l}\text { 编码蛋白 } \\
\text { Encoded } \\
\text { protein }\end{array}$ & 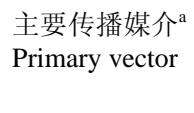 & $\begin{array}{l}\text { 感染宿主 }^{a} \\
\text { Host }\end{array}$ \\
\hline $\begin{array}{l}\text { 番茄斑萎病 } \\
\text { 毒科 } \\
\text { Tospoviridae }\end{array}$ & $\begin{array}{l}\text { 正番茄斑萎病毒属 } \\
\text { Orthotospovirus }\end{array}$ & $\begin{array}{l}\text { 正番茄斑萎病毒 } \\
\text { Tomato spotted wilt } \\
\text { orthotospovirus }\end{array}$ & $\begin{array}{l}\text { 有囊膜 } \\
\text { 球形 } \\
\text { 直径80-120 nm } \\
\text { Enveloped } \\
\text { Spherical virion } \\
80-120 \mathrm{~nm} \text { in diameter }\end{array}$ & $\begin{array}{l}\text { 单链负义三节段RNA: } \\
\text { L: } 8.6-8.9 \mathrm{~kb} \\
\text { M: } 4.7-5.0 \mathrm{~kb} \\
\text { S: } 2.5-3.6 \mathrm{~kb} \\
\text { Tri-segmented genome of negative } \\
\text { sense single-stranded RNA: } \\
\text { L: } 8.6-8.9 \mathrm{~kb} \\
\text { M: } 4.7-5.0 \mathrm{~kb} \\
\text { S: } 2.5-3.6 \mathrm{~kb}\end{array}$ & $\begin{array}{l}\text { L: RdRp } \\
\text { M: GP (Gn, Gc, } \\
\text { NSm) } \\
\text { S: NP, NSs }\end{array}$ & $\begin{array}{l}\text { 蓟马 } \\
\text { Thrips }\end{array}$ & $\begin{array}{l}\text { 主要为双子叶和单子叶植物 } \\
\text { Mainly dicotyledonous and } \\
\text { monocotyledonous plants }\end{array}$ \\
\hline
\end{tabular}

a 昆虫宿主限制性病毒; 尚未有人或动物感染的报道

b 昆虫宿主限制性病毒; 尚未有感染其他节肢动物或脊椎动物的报道

c 该属双忝昆虫病毒1的M基因编码GP (Gn, NSm, Gc)

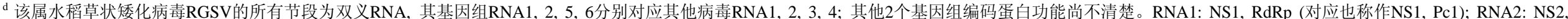

NSvc2 (也称作P2, Pc2); RNA3: NS3, NSvc3 (也称作P3, Pc3); RNA4: NS4, NSvc4 (也称作P4, Pc4); RNA5: NS5, CP (也称作P5, Pc5); RNA6: SP, NSvc6 (也称作P6, Pc6)

e 有学者报道该属裂谷热病毒编码Gn, Gc, NSm1, NSm2 (Won et al, 2006; Gerrard \& Nichol, 2007)

${ }^{a}$ Insect-specific viruse; no Homo Sapiens or animal infection cases have been reported

${ }^{b}$ Insect-specific viruse; no Homo Sapiens or animal infection has been reported. No other arthropods or vertebrates infection have been reported

${ }^{c} \mathrm{GP}$ (Gn, NSm, Gc) proteins are encoded by M gene of SHUV-1

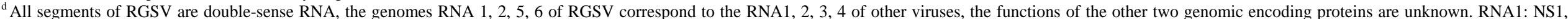

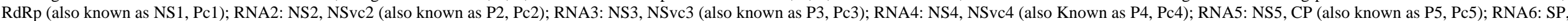

NSvc6 (also known as P6, Pc6)

e Some other scholars have reported that Gn, Gc, NSm1, and NSm2 are encoded by Rift valley fever virus (Won et al, 2006; Gerrard \& Nichol, 2007) 
唐霜，沈姝，史君明，方耀辉，王华林，胡志红，邓菲. 布尼亚病毒目新分类概述. 生物多样性, 2018, 26 (9): 1004-1015.

http://www.biodiversity-science.net/CN/10.17520/biods.2018042

附录 2 布尼亚病毒缩写和 $\mathrm{L}$ 片段序列号

Appendix 2 Bunyavirus abbreviations and L segment accession numbers

\begin{tabular}{|c|c|c|c|c|}
\hline 科 & 属 & 全称 & 缩写 & L 片段序列号 \\
\hline Family & Genus & Full name & Abbreviation & Accession no. \\
\hline \multirow[t]{22}{*}{ 汉坦病毒科 Hantaviridae } & 正汉坦病毒属 Orthohnatavirus & Andes virus & ANDV & NC003468 \\
\hline & & Amur virus & AMRV & JX473002 \\
\hline & & Anjozorobe virus & ANJV & KC490923 \\
\hline & & Bayou virus & BAYV & GQ244526 \\
\hline & & Bowe virus & BOWV & KC631784 \\
\hline & & Cano Delgadito virus & CDGV & GQ200821 \\
\hline & & Cao Bang virus & $\mathrm{CBNV}$ & EF543525 \\
\hline & & Choclo virus & $\mathrm{CHOV}$ & EF397003 \\
\hline & & Dobrava-Belgrade virus & DOBV & GU904044 \\
\hline & & Luxi virus & LUXV & HQ404253 \\
\hline & & Hantaan virus & HTNV & KT934989 \\
\hline & & Hokkaido virus & HOKV & AB712372 \\
\hline & & Imjin virus & MJNV & KJ420567 \\
\hline & & Jeju virus & JJUV & HQ834697 \\
\hline & & Kenkeme virus & KKMV & KJ857320 \\
\hline & & Khabarovsk virus & KHAV & KJ857312 \\
\hline & & Laibin virus & LBV & KM102249 \\
\hline & & Montano virus & MTNV & AB620102 \\
\hline & & Nova virus & NVAV & KT004447 \\
\hline & & Puumala virus & PUUV & KJ994778 \\
\hline & & Rio Mamoré virus & RIOMV & FJ809772 \\
\hline & & Rockport virus & RKPV & HM015221 \\
\hline
\end{tabular}


唐霜, 沈姝, 史君明, 方耀辉, 王华林, 胡志红, 邓菲. 布尼亚病毒目新分类概述. 生物多样性, 2018, 26 (9): 1004-1015. http://www.biodiversity-science.net/CN/10.17520/biods.2018042

\begin{tabular}{|c|c|c|c|c|}
\hline 科 & 属 & 全称 & 缩写 & L 片段序列号 \\
\hline \multirow[t]{7}{*}{ Family } & Genus & Full name & Abbreviation & Accession no. \\
\hline & & Sangassou virus & SANGV & JQ082302 \\
\hline & & Seoul virus & SEOV & KР645196 \\
\hline & & Sin Nombre virus & SNV & L37902 \\
\hline & & Soochong virus & SOOV & DQ056292 \\
\hline & & Thottapalayam virus & TPMV & NC010707 \\
\hline & & Tula virus & TULV & NC005226 \\
\hline \multirow[t]{12}{*}{ 白纤病毒科 Phenuiviridae } & 白蛉病毒属 Phlebovirus & Rift Valley fever virus & RVFV & KX096941 \\
\hline & & Munguba/Bujaru virus & MUNV & HM566164 \\
\hline & & Candiru virus & CDUV & NC015374 \\
\hline & & Sandfly fever Sicilian virus & SFSV & KM042102 \\
\hline & & SFTS virus & SFTSV & KC292327 \\
\hline & 格克病毒属 Goukovirus & Gouleako virus & GOLV & HQ541738 \\
\hline & & Cumuto virus & CUMV & KF543244 \\
\hline & & Yíchang insect virus & YCIV & KM817703 \\
\hline & 帕西病毒属 Phasivirus & Phasi chareon virus & PCLV & KR003786 \\
\hline & & Badu virus & BADUV & KT693187 \\
\hline & & Wutai Mosquito virus & WTMV & KM817700 \\
\hline & 纤细病毒属 Tenuivirus & Rice stripe virus & RSV & NC003755 \\
\hline \multirow[t]{4}{*}{ 内罗病毒科 Nairoviridae } & 正内罗病毒属 Orthonairovirus & Hazare virus & HAZV & KР406723 \\
\hline & & Keterah virus & KTRV & KR537447 \\
\hline & & Nairobi sheep disease virus & NSDV & KM464726 \\
\hline & & Crimean-Congo hemorrhagic fever virus & CCHFV & JN572090 \\
\hline
\end{tabular}


唐霜, 沈姝, 史君明, 方耀辉, 王华林, 胡志红, 邓菲. 布尼亚病毒目新分类概述. 生物多样性, 2018, 26 (9): 1004-1015. http://www.biodiversity-science.net/CN/10.17520/biods.2018042

\begin{tabular}{|c|c|c|c|c|}
\hline 科 & 属 & 全称 & 缩写 & L 片段序列号 \\
\hline \multirow[t]{7}{*}{ Family } & Genus & Full name & Abbreviation & Accession no. \\
\hline & & Dera Ghazi Khan virus & DGKV & KU925452 \\
\hline & & Dugbe virus & DUGV & NC004159 \\
\hline & & Hughes virus & HUGV & KU925470 \\
\hline & & Qualyub virus & QYBV & KU925476 \\
\hline & & Tillamook virus & TILLV & KU925494 \\
\hline & & Thiafora virus & TFAV & KR537450 \\
\hline \multirow[t]{4}{*}{ 番茄斑萎病毒科 Tospoviridae } & 正番茄斑萎病毒属 Orthotospovirus & Groundnut ringspot virus & GRSV & KT972590 \\
\hline & & Impatiens necrotic spot virus & INSV & NC003625 \\
\hline & & Tomato spotted wilt virus & TSWV & JF960237 \\
\hline & & Watermelon silver mottle virus & WSMoV & JX177647 \\
\hline \multirow{11}{*}{$\begin{array}{l}\text { 泛布尼亚病毒科 } \\
\text { Perbunyaviridae }\end{array}$} & 赫伯病毒属 Herbevirus & Herbert virus & HEBV & KF590586 \\
\hline & & Tai virus & TAIV & KF590574 \\
\hline & & Kibale virus & KIBV & KF590577 \\
\hline & & Shuangao insect virus 1 & SGIV1 & NC031221 \\
\hline & 正布尼亚病毒属 Orthobunyavirus & Akabane virus & AKAV & KR260716 \\
\hline & & Alajuela virus & ALAV & KM272186 \\
\hline & & Leanyer virus & LEAV & HM627178 \\
\hline & & Trivittatus virus & TVTV & KR149249 \\
\hline & & Abbey Lake virus & Ab-BUNV & KJ710425 \\
\hline & & Calovo virus & CVOV & KC608155 \\
\hline & & La Crosse virus & LACV & GU591166 \\
\hline
\end{tabular}


唐霜, 沈姝, 史君明, 方耀辉, 王华林, 胡志红, 邓菲. 布尼亚病毒目新分类概述. 生物多样性, 2018, 26 (9): 1004-1015. http://www.biodiversity-science.net/CN/10.17520/biods.2018042

\begin{tabular}{|c|c|c|c|c|}
\hline 科 & 属 & 全称 & 缩写 & L 片段序列号 \\
\hline Family & Genus & Full name & Abbreviation & Accession no. \\
\hline & & Gamboa virus & GAMV & KT950266 \\
\hline & & Brazoran virus & BRAV & NC022039 \\
\hline & & Oropouche virus & OROV & KР691606 \\
\hline & & Oya virus & OYAV & JX983194 \\
\hline & & Tete virus & TETEV & KP792681 \\
\hline & & Keystone virus & KEYV & KT630291 \\
\hline \multirow[t]{6}{*}{ 无花果花叶病毒科 Fimoviridae } & 伊马拉病毒属 Emaravirus & European mountain ash ringspot-associated virus & EMARaV & AY563040 \\
\hline & & Fig mosaic virus & FMV & NC029562 \\
\hline & & High plains wheat mosaic virus & HPWMoV & NC029570 \\
\hline & & Pigeonpea sterility mosaic virus & PPSMV & NC029575 \\
\hline & & Raspberry leaf blotch virus & RLBV & NC029567 \\
\hline & & Rose rosette virus & RRV & NC015298 \\
\hline \multirow[t]{4}{*}{ 幻影病毒科 Phasmaviridae } & 正幻影病毒属 Orthophasmavirus & Kigluaik phantom virus & KIGV & KJ434182 \\
\hline & & Nome Phantom virus & NOMV & KJ434185 \\
\hline & & Wuhan mosquito virus 2 & WHMV2 & KM817698 \\
\hline & & Wuchang cockroach virus 1 & WCCV1 & KM817688 \\
\hline 费拉病毒科 Feraviridae & 正费拉病毒属 Orthoferavirus & Ferak virus & FERV & KP710246 \\
\hline 米卡多病毒科 Jonviridae & 正米卡多病毒属 Orthojonvirus & Jonchet virus & JONV & KP710232 \\
\hline
\end{tabular}

